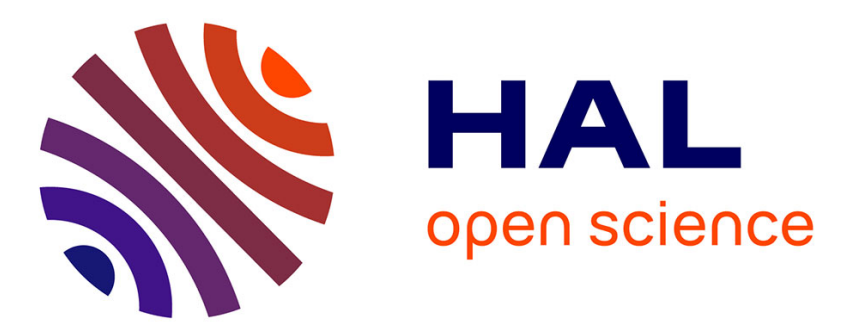

\title{
The concentration of bone-related organic additives drives the pathway of apatite formation
}

Marc Robin, Camila B Tovani, Jean-Marc Krafft, Guylène Costentin, Thierry Azaïs, Nadine Nassif

\section{> To cite this version:}

Marc Robin, Camila B Tovani, Jean-Marc Krafft, Guylène Costentin, Thierry Azaïs, et al.. The concentration of bone-related organic additives drives the pathway of apatite formation. Crystal Growth \& Design, 2021, 21 (7), pp.3994-4004. 10.1021/acs.cgd.1c00316 . hal-03335945

\section{HAL Id: hal-03335945 \\ https: / hal.sorbonne-universite.fr/hal-03335945}

Submitted on 6 Sep 2021

HAL is a multi-disciplinary open access archive for the deposit and dissemination of scientific research documents, whether they are published or not. The documents may come from teaching and research institutions in France or abroad, or from public or private research centers.
L'archive ouverte pluridisciplinaire HAL, est destinée au dépôt et à la diffusion de documents scientifiques de niveau recherche, publiés ou non, émanant des établissements d'enseignement et de recherche français ou étrangers, des laboratoires publics ou privés. 


\section{The concentration of bone-related organic additives}

\section{drives the pathway of apatite formation}

Marc Robin ${ }^{1 \S}$, Camila B. Tovani ${ }^{1 \S}$, Jean-Marc Kraffi ${ }^{2}$, Guylène Costentin ${ }^{2 *}$, Thierry Azaïs ${ }^{1}$, Nadine Nassif ${ }^{*}$

1. Sorbonne Université, CNRS, Collège de France, Laboratoire Chimie de la Matière Condensée de Paris, LCMCP, F-75005 Paris, France.

2. Sorbonne Université, CNRS, Laboratoire Réactivité de Surface, LRS, F-75005 Paris, France.

$\S$ These authors contributed equally to this work

*Corresponding author e-mail:

guylene.costentin@sorbonne-universite.fr,nadine.nassif@sorbonne-universite.fr

Keywords: biomineralization, calcium phosphate, additives, biopolymers, confinement 


\section{Abstract}

Bone models set for studying apatite mineralization tend to use excess of organic additives and a very low concentration of collagen in the light of those described in the biological tissue. However, the activity of soluble additives during mineral deposition is highly dependent on their concentration and confinement state, among others. Here, we investigate the role of concentration of organic additives described as key components in bone mineralization, i.e. the bioinspired synthetic polyaspartate mimicking non-collagenous protein (NCP), citrate and collagen, on apatite formation. The precipitation set-up tends to mimic the acidic mineralization front in bone and was monitored by in situ Raman and ex situ solid-state nuclear magnetic resonance (ssNMR). This model helps to identify specific effects of organic additives on mineral formation. In particular, we show that the sequence of apatite precursors often described in vitro, i.e. amorphous calcium phosphate (ACP) and subsequent octacalciumphosphate (OCP) formation, is noticeably modified by varying the concentration of the additives. NCP and citrate are identified as either inhibitor or activator in the formation of calcium phosphate $(\mathrm{CaP})$. Besides, collagen acts either as additives or as organic scaffold below and above the liquid-crystal threshold, respectively. This result highlights that confinement drives thermodynamically apatite formation by slowing down the kinetic formation of precursors, even at alkaline $\mathrm{pH}$. 


\section{INTRODUCTION}

Biomineralization is a multistep process whereby organisms create fascinating multifunctional hybrid structures displaying hierarchical organization and well-defined crystal size, morphology, spatial orientation and polymorphs selection. ${ }^{1}$ The synergism between the inorganic precursors and the organic matrix present in the biomineralization medium leads to materials with enhanced mechanical resistance and distinctive optical properties as compared to their synthetic counterparts. ${ }^{2,3}$ This is greatly exemplified by bone, a biohybrid material recently described as a fractal-like organization. ${ }^{4}$ At the mineralization front, bone mineral is deposited as nanometric crystals with a platelet morphology and their $c$ axis coaligned along the type I collagen fibrils. ${ }^{5,6}$

The preferred orientation of apatite crystals within the organic matrix and the development of pathological calcification driven by the deficiency in specific biomolecules strengthen their control over the nucleation and growth processes ${ }^{7,8}$ However, the exact role of organic molecules on bone mineralization is still under debate.

Type I collagen (30 wt.\% of bone and $90 \mathrm{wt} . \%$ of the organic components in bone) is described to nucleate bioapatite by binding $\mathrm{Ca}^{2+}$ on its charged amino acids residues. ${ }^{9-11}$ Moreover, the assembly of collagen molecules into a dense and fibrillar matrix provides a confined environment i.e. inter- and intrafibrillar spaces, that also support the supersaturation of the ionic precursors of bone mineral. ${ }^{12}$ Indeed, the structure, the size and the three-dimensional distribution of bioapatite at larger length scales are described to arise due to confinement effects. ${ }^{12,13}$

In addition to collagen, non-collagenous proteins (NCPs) and other type of organic species such as citrate are also reported to be involved in time and space in the mineralizing front of bone. ${ }^{14-16}$ Among the NCPs, osteopontin, osteocalcin and osteonectin are proposed to control the 
nucleation of amorphous calcium phosphate (ACP) and its further conversion into apatite. ${ }^{17-19} \mathrm{~A}$ common characteristic of the selected NCPs is the presence of carboxylic acidic groups that create a high density of negatively charged domains with chemical affinity for $\mathrm{Ca}^{2+}$ and apatite surface. In this sense, calcium-binding polymers have been extensively used to mimic NCPs, specially poly(aspartic acid) (pAsp), leading to the observation of a polymer induced liquid precursor (PILP). ${ }^{20-22}$ In vitro studies have demonstrated that pAsp forms negatively charged ACP complexes that infiltrate the gap zones by interacting with positively charged domains in the collagen fibrils at the early stages of apatite mineralization. ${ }^{11,23,24}$

Citrate is an abundant component of the bone organic matrix ( $2 \mathrm{wt} . \%$ of bone or $5 \mathrm{wt} . \%$ of the organic components) that plays multiple roles on bioapatite mineralization. ${ }^{25-27}$ Solid state nuclear magnetic resonance (ssNMR) studies evidenced citrate as an interfacial and strongly bounded molecule in bone. ${ }^{28,29}$ It was proposed that citrate binds to the facets of apatite crystals preventing disordered growth thus controlling bone mineral in terms of size and morphology. ${ }^{30-33}$ Apart from this, citrate foster the nucleation of ACP and its subsequent intrafibrillar mineralization by decreasing the interfacial energy between collagen and the mineral in vitro. ${ }^{34}$

Although the involvement of the collagen matrix, citrate and NCP appear clear, the way they act in space and time in bioapatite formation remains as a fundamental question. This may be partially explained by the fact that the use of high non-physiological concentrations of organic additives tends to stabilize kinetic $\mathrm{CaP}$ phases that are maybe not found in bone. Still, most studies on biomineralization rely on ex situ characterization of the products, which may lead to structural changes in the metastable phases due to dehydration during the isolation process and analysis. Thus, combining in situ to ex situ studies is of high interest to strengthen the conclusions. 
Considering the challenges in probing the kinetic of the mineralization process, herein, in situ Raman and ex situ solid-state nuclear magnetic resonance (ssNMR) were used to depict the formation and structural evolution of biomimetic apatite in a bioinspired mineralization front containing collagen or the additives pAsp and citrate at varying concentrations. By doing so, it is possible to unveil the specific role of bone additives on the $\mathrm{CaP}$ precipitation (formation and stabilization). In situ Raman and ex situ ssNMR are non-invasive techniques allowing the study of $\mathrm{CaP}$ phases while preserving their hydration state and preventing from artifacts inherent of isolation processes. Strikingly, pAsp increases the lifetime of kinetic $\mathrm{CaP}$ intermediates while citrate at physiological concentrations stabilizes ACP. In contrast, collagen determines the structural properties of apatite regardless its concentration. Nevertheless, its role as organic scaffold in driving thermodynamically the apatite formation is only observed above the liquidcrystal threshold.

Unraveling the contribution of biomolecules during the pathway of mineral deposition and assembly in bone contributes significantly to the understanding of morphogenesis and further diseases caused by pathological mineralization; it also should be useful for the design of biomimetic materials with suitable properties. 


\section{EXPERIMENTAL}

\subsection{Formation of biomimetic apatite within a bioinspired mineralization front containing organic additives and collagen}

\subsubsection{Precipitation in solution with citrate or pAsp}

The organic additives pAsp or citrate were dissolved in acidic aqueous solution containing the ionic precursors of apatite $\mathrm{CaCl}_{2} \cdot 2 \mathrm{H}_{2} \mathrm{O}$ (110 mM, Sigma), $\mathrm{NaH}_{2} \mathrm{PO}_{4}$ (33 mM, Sigma), and $\mathrm{NaHCO}_{3}(33 \mathrm{mM}$, Sigma). The $\mathrm{Ca} /(\mathrm{P}+\mathrm{C})$ ratio was equal to 1.67 and the $\mathrm{pH}$ was adjusted to 2.5 with hydrochloric acid $50 \mu \mathrm{g} \mathrm{mL} \mathrm{L}^{-1}$ PolyAsp (L-aspartic acid sodium salt Bayer $1200 \mathrm{~g} \mathrm{~mol}^{-1}$ ) was used according to the more common procedures found in the literature. ${ }^{35}$ The content of citrate in bone is approximately $2 \%$ in mass. ${ }^{25,27}$ Therefore, different concentrations of trisodium citrate $(2.00,0.25,0.10$ and $0.05 \mathrm{wt} . \%$ corresponding to $68.0,8.3,3.4$ and $1.7 \mathrm{mM})$ were used in relation to the ionic precursors. As described previously, two flasks $(35 \mathrm{~mL}$, height $=50 \mathrm{~mm})$ containing the mixtures $(20 \mathrm{~mL})$ and covered with perforated Parafilm were placed in a $1 \mathrm{~L}$ beaker. ${ }^{36} \mathrm{~A}$ third flask containing fresh aqueous ammonia solution $(30 \mathrm{wt} . \%, 8 \mathrm{~mL})$ was placed in the beaker that was sealed with Parafilm. $\mathrm{NH}_{3}(\mathrm{~g})$ diffusion into the flasks at ambient temperature slowly increases the $\mathrm{pH}$ of the solutions triggering the precipitation of calcium phosphate $(\mathrm{CaP})$. After six days of reaction ( $\mathrm{pH} \sim 10-11$ ), the solids were washed with distilled water then ethanol, to remove soluble salts and non-bonded molecules, centrifuged (6000 rpm, $10 \mathrm{~min})$ and characterized. The CaP precipitation in the presence of organic additives was complementary monitored by in situ Raman and ex situ ssNMR. The control experiment, i.e. the precipitation of biomimetic apatite in the absence of additives in the same conditions, is described elsewhere. ${ }^{37}$ ACP reference sample was prepared as described elsewhere. ${ }^{38}$ 


\subsubsection{Precipitation in the presence of different concentrations of collagen}

Different concentrations of collagen were used in the precipitation of apatite: a low one (2 $\mathrm{mg} \mathrm{mL}^{-1}$ ) according to the procedures commonly found in the literature and, higher concentrations to form organizations resembling those of the native (i) osteoid $\left(40 \mathrm{mg} \mathrm{mL}^{-1}\right)$ and (ii) compact bone $(250 \mathrm{mg} \mathrm{mL}-1) \cdot{ }^{39}$ All the solutions were prepared in acetic acid $(500 \mathrm{mM})$. Collagen was extracted from rat tail tendons following a classical procedure. ${ }^{40}$ For the $2 \mathrm{mg} \mathrm{mL}{ }^{-1}$ system, the ionic precursors of apatite were dissolved in the collagen acidic solution $(\mathrm{pH}=2.5)$. The $40 \mathrm{mg} \mathrm{mL}{ }^{-1}$ system was prepared by an evaporation procedure. ${ }^{41}$ Accordingly, $100 \mathrm{~mL}$ of collagen acid solution $\left(2 \mathrm{mg} \mathrm{mL}^{-1}\right)$ containing the ionic precursors of apatite was left open under a laminar flow hood for about 12 hours. This allows the evaporation of the acetic acid/water present in the solution leading to the desired concentration of collagen. $250 \mathrm{mg} \mathrm{mL}^{-1}$ collagen matrices were formed using a procedure described elsewhere which combines injection and reverse dialysis. $^{12,42}$ Succinctly, an acidic collagen solution at low concentration $\left(\sim 2 \mathrm{mg} \mathrm{mL}^{-1}\right)$ is continuously injected in a disk-shaped dialysis chamber which is in contact with a polyethylene glycol solution (molecular weight cut off of $12-14 \mathrm{kDa}$ ). The polyethylene glycol solution is prepared by dissolving the polymer (PEG, $35 \mathrm{kDa}$, Fluka) in the acidic solution containing ionic precursors of apatite that was used for collagen. The concentration of the PEG solution controls the final concentration of collagen in the chamber. For all the samples, both fibrillogenesis of collagen and precipitation of mineral were trigged by the increase of $\mathrm{pH}$ to a range of 10 by $\mathrm{NH}_{3}$ diffusion. The collagen concentration was determined by hydroxyproline titration. ${ }^{43}$ The temporal evolution of mineral in the $250 \mathrm{mg} \mathrm{mL}^{-1}$ system was investigated ex situ by ssNMR. To this end, the reaction was stopped at different intervals of time and the mineral characterized immediately 
by ${ }^{31} \mathrm{P}$ ssNMR. The $2 \mathrm{mg} \mathrm{mL}^{-1}$ and $40 \mathrm{mg} \mathrm{mL}^{-1}$ systems were investigated in situ by Raman spectroscopy.

\subsection{Fresh bone sample}

Bone was extracted from the proximal part of the diaphysis and distal epiphysis of the humerus and femur from 2-year-old healthy French sheep. The study was reviewed and approved by the IMM Recherche's Institutional Animal Care and Use committee (IACUC) prior to starting. The animal research received an agreement $\left(n^{\circ} 75-14-01\right)$ on September $08^{\text {th }}, 2013$ for a period of 5 years by the "Sous-Direction de la protection Sanitaire" of the French Authorities.

\subsection{Following the precipitation of biomimetic apatite in situ using micro-Raman spectroscopy}

In situ Raman spectroscopy was used to monitor the evolution of $\mathrm{CaP}$ precipitation. The spectra were acquired with a KAISER Optical system equipped with a charge coupled detector (CCD) and a LASER with $\lambda=785 \mathrm{~nm}\left(\mathrm{P}=10-12 \mathrm{~mW}\right.$, resolution $=4 \mathrm{~cm}^{-1}$ accumulation time $=$ 150 seconds, 6 scans per spectrum, 1 spectrum every 16 minutes) using a fiber optic Raman probe equipped with a sapphire optical lens. The probe was immersed directly in the upper $2 / 3$ of the ionic solution of one of the two flasks. $\mathrm{NH}_{3}(\mathrm{~g})$ was then introduced, and the chamber closed. The probe was maintained fixed during the precipitation to avoid artefacts. A homemade optical set up was used in the presence of collagen due to optical perturbations induced by the precipitation of fibrils. The set-up allows remote analysis from the optical head (MR-Probe-785) of the Raman spectrometer (Kaiser optical systems, Raman analyzer RXN1). The device is based on a principle similar to that of the immersion probe and involves a mounting that was screwed onto the optical head and consists of an aluminum tube with threaded ends carrying a 10x lens. The whole assembly 
was wrapped with PTFE as illustrated in Figure S1. Spectral analysis and decompositions were performed using GRAM/AI software.

\subsection{Ex situ characterization}

The final products were isolated, washed with ultra-pure water and dried at $37^{\circ} \mathrm{C}$, then characterized as follow.

Ex situ micro-Raman. After 6 days of reaction the final products were characterized ex situ by micro-Raman using a KAISER Optical system equipped with a charge coupled detector (CCD) and a LASER with $\lambda=785 \mathrm{~nm}\left(\mathrm{P}=10-12 \mathrm{~mW}\right.$, resolution $=4 \mathrm{~cm}^{-1}$ accumulation time $=20 \mathrm{~s}, 5$ scans per spectrum) coupled with a microscope with a 50x lens.

Transmission electron microscopy. A transmission electron microscope (TEM JEOL 2011) operating at $200 \mathrm{keV}$ was used to obtain the TEM images. To this end, the samples were dispersed in ethanol and some drops were deposited on a lacey carbon film on copper grid.

Solid state NMR. ${ }^{1} \mathrm{H}$ and ${ }^{31} \mathrm{P}$ ssNMR experiments were conducted on an Avance 500 Bruker spectrometer operating at $v\left({ }^{1} \mathrm{H}\right)=500.13 \mathrm{MHz}, v\left({ }^{31} \mathrm{P}\right)=202.40 \mathrm{MHz}$ and $v\left({ }^{13} \mathrm{C}\right)=125.03 \mathrm{MHz}$. The $\mathrm{t} 90^{\circ}\left({ }^{1} \mathrm{H}\right), \mathrm{t} 90^{\circ}\left({ }^{31} \mathrm{P}\right)$ and $\mathrm{t} 90^{\circ}\left({ }^{13} \mathrm{C}\right)$ were set to $4.5 \mu \mathrm{s}, 5.5$ and $5.5 \mu \mathrm{s}$, respectively. The powders were packed in $4 \mathrm{~mm}$ zirconia rotors and spun at $8-14 \mathrm{kHz} .{ }^{31} \mathrm{P}$ direct acquisition spectra were recorded in quantitative conditions used a recycle delay (RD) of $200 \mathrm{~s}$ and a $30^{\circ}$ pulse, the number of scans (NS) were set to 80 . The $2 \mathrm{D}{ }^{1} \mathrm{H}^{3}{ }^{31} \mathrm{P}$ HetCor spectra were recorded using the following parameters $\mathrm{RD}=2 \mathrm{~s}$; contact time $\mathrm{t}_{\mathrm{CP}}=1 \mathrm{~ms}, \mathrm{NS}=32-80$ for each 40-120 $\mathrm{t}_{1}$ increments depending on the sample. The ${ }^{1} \mathrm{H}_{-}{ }^{13} \mathrm{C}$ CP MAS spectra were recorded using a contact time of $1 \mathrm{~ms}$. The chemical shifts were referenced (0 ppm) to $\mathrm{H}_{3} \mathrm{PO}_{4} 85$ wt. $\%$ for ${ }^{31} \mathrm{P}$ and TMS for ${ }^{1} \mathrm{H}$ and ${ }^{13} \mathrm{C}$. 


\section{RESULTS}

\subsection{Effect of pAsp on CaP precipitation}

Precipitation and subsequent conversion of $\mathrm{CaP}$ phases over the mineralization process were tracked by following in situ the evolution of the $v_{1} \mathrm{PO}_{4}$ band (symmetric stretch) in the Raman spectra (Figure 1A). Without any additives (referred as "control" experiment), the precipitation of biomimetic apatite occurs through the following sequence: amorphous calcium phosphate (ACP, $1.5 \mathrm{~h})$, octacalcium phosphate (OCP, $2.5 \mathrm{~h}), \mathrm{CHA}(>10 \mathrm{~h}) .{ }^{37}$

In the presence of pAsp, a weak and broad band at $951 \mathrm{~cm}^{-1}$ ascribed to the $v_{1} \mathrm{PO}_{4}$ typical of ACP is observed in the Raman spectrum after $11 \mathrm{~h}$. This higher induction time compared to that observed for the control experiment evidences the inhibitory effect of pAsp on the nucleation of CaP. After 19h, the arising of two shoulders at 953 and $962 \mathrm{~cm}^{-1}$ shows the crystallization of ACP into OCP. The sharpening of the main band (FWHM $\left.=17 v s .14 \mathrm{~cm}^{-1}\right)$ occurring with time (18$22 \mathrm{~h}$ ) indicates that OCP becomes more crystalline upon maturation. Sequentially (from $25 \mathrm{~h}$ ), the OCP characteristic shoulder at $962 \mathrm{~cm}^{-1}$ disappears indicating the transformation of OCP into a poorly crystalline apatite. As the mineralization proceeds $(>25 \mathrm{~h})$, the hydroxyapatite maturation is revealed by the sharpening of the $\mathrm{PO}_{4}{ }^{3-}$ band and the shift towards $958 \mathrm{~cm}^{-1}$.

After 6 days of reaction, the product (CHA-pAsp) was isolated and characterized ex situ to investigate the effects of pAsp on the structure (Figure 1B-C) and morphology (Figure 1D) of apatite. Observations on TEM (Figure 1D) shows that CHA-pAsp is composed of aggregated platelets resembling to that found without additives (CHA) (Figure S2A). The ex situ microRaman spectra of CHA and CHA-pAsp are compared in Figure 1B. No significant differences (position, FWHM of $v_{1} \mathrm{PO}_{4}$ ) were noted which suggests that pAsp did not impact on the structural features of biomimetic apatite. The direct ${ }^{31} \mathrm{P}$ MAS NMR spectrum for CHA-pAsp displays a main 
signal at $\delta\left({ }^{31} \mathrm{P}\right)=2.8 \mathrm{ppm}$ typical of $\mathrm{PO}_{4}{ }^{3-}$ in apatitic environment (Figure $1 \mathrm{C}$, red line). The ${ }^{1} \mathrm{H} \rightarrow{ }^{31} \mathrm{P}$ CP MAS spectra were also recorded for CHA-pAsp ( $\mathrm{t}_{\mathrm{cp}}=1 \mathrm{~ms}$; Figure 1C, blue line). This experiment evidences protonated chemical environments around ${ }^{31} \mathrm{P}$ thanks to magnetization transfer from protons in spatial proximity. The ${ }^{1} \mathrm{H}_{-}{ }^{31} \mathrm{P}$ CPMAS spectrum emphasizes two extra resonances ascribed to $\mathrm{HPO}_{4}^{-}$from $\mathrm{OCP}$ at $\delta\left({ }^{31} \mathrm{P}\right) \sim 1.5$ and $\sim-0.3 \mathrm{ppm}$. According to previous investigations of reference samples ${ }^{37}$, the proportion of OCP is estimated to $10 \%$. The asymmetric resonance on the left side (red arrow) is evidenced using such short $t_{c p}$ and is related to the contribution of the amorphous layer of apatite and to a less extend to ortho-phosphate sites in OCP. Notably, OCP is not detected in the ${ }^{31} \mathrm{P}$ ssNMR spectra of the control emphasizing the ability of pAsp to stabilize this intermediate phase of CHA (Figure S2B). 

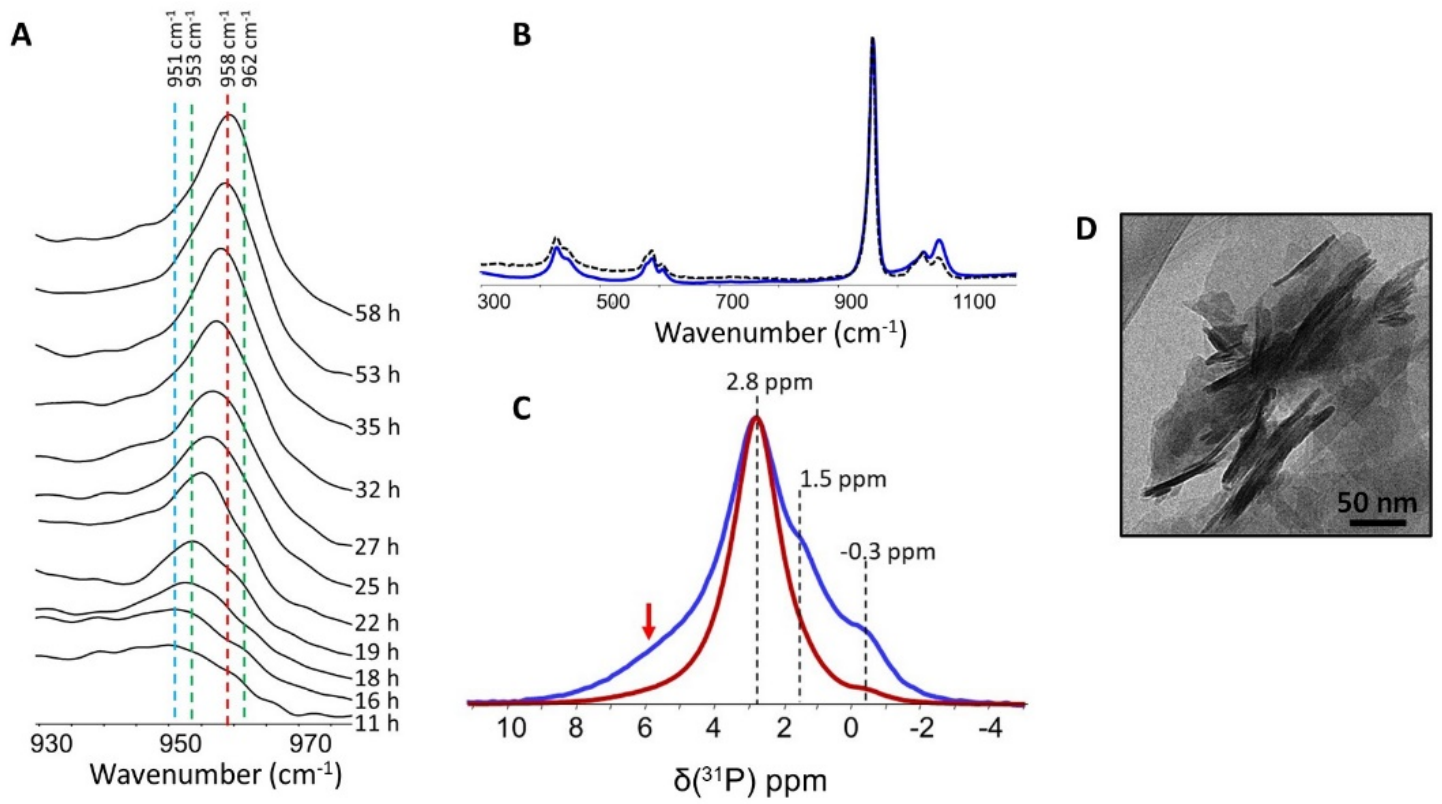

Figure 1. Formation of apatite in the presence of $50 \mu \mathrm{g} \mathrm{mL}^{-1} \mathrm{pAsp}$. (A) In situ monitoring of mineralization by Raman spectroscopy. The blue line $\left(951 \mathrm{~cm}^{-1}\right)$, green lines $\left(953\right.$ and $\left.962 \mathrm{~cm}^{-1}\right)$ and red line $\left(958 \mathrm{~cm}^{-1}\right)$ represent the ACP, OCP and the apatite contributions, respectively. (B) Comparison between ex situ microRaman spectra of CHA-pAsp (blue line) and CHA (dashed black line). (C) Quantitative ${ }^{31}$ P MAS NMR (red line) and ${ }^{1} \mathrm{H} \rightarrow{ }^{31} \mathrm{P}$ CP MAS ( $\mathrm{t}_{\mathrm{cp}}=1 \mathrm{~ms}$; blue line) spectra of CHA-pAsp. The asymmetric resonances on the right correspond to $\mathrm{HPO}_{4}{ }^{2-}$ from OCP and on the left side (red arrow) is related to the contribution of the amorphous layer of apatite and to a less extend to ortho-phosphate sites in OCP. (D) TEM images of CHA-pAsp. 


\subsection{Effect of citrate on CaP precipitation}

We first investigated the precipitation of biomimetic apatite in the presence of $2 \mathrm{wt} . \%$ citrate, which is the concentration described in bone (Figure 2A). ${ }^{25,27}$ At $\mathrm{t}=0$, the in situ Raman spectrum displays a large band in the region of $900-940 \mathrm{~cm}^{-1}$ assigned to the carbon-carbon stretching modes $v(\mathrm{C}-\mathrm{COO})$ from citrate chain. ${ }^{44}$ After $3 \mathrm{~h}$, a shoulder at $951 \mathrm{~cm}^{-1}$ is observed indicating the formation of ACP. The longer induction time in comparison with the control (1.5h) shows that citrate delays the nucleation of $\mathrm{CaP}$. This band intensifies as the reaction proceeds (at least for 27h) indicating the stabilization of ACP. The same precipitation pathway is found when the concentration of citrate is about 10 times lower than that found in vivo $(0.25 \mathrm{wt} . \%)$ and $\mathrm{ACP}$ is not converted into apatite at least during the in situ Raman monitoring (Figure 2B). Then, the reaction was performed for 6 days and the products were isolated and characterized by ex situ TEM, ssNMR and micro-Raman spectroscopy. The Raman spectra of a pure ACP sample and the isolated products precipitated in the presence of $2 \mathrm{wt} . \%$ citrate (ACP-cit2\%) and $0.25 \mathrm{wt} . \%$ citrate (ACP-cit0.25\%) are compared in Figure 2C. The similarities between the spectra of ACP-citrate and pure synthetic ACP samples confirm the stabilization of amorphous precursor even after 6 days of reaction. Notably, ACP-cit2\% displays larger Raman band as compared to ACP-cit0.25\% indicating a higher degree of disorder. The ${ }^{31} \mathrm{P}$ MAS NMR spectrum of ACP-cit $0.25 \%$ (red line) shows a resonance peak centered at $\delta\left({ }^{31} \mathrm{P}\right)=3.2 \mathrm{ppm}$ typical of ACP (Figure 2D). In addition, the broadening of the ${ }^{31} \mathrm{P}$ resonance seen on the ${ }^{1} \mathrm{H}_{-}{ }^{31} \mathrm{P}$ CP MAS NMR spectrum $\left(\mathrm{t}_{\mathrm{cp}}=1 \mathrm{~ms}\right.$; blue line $)$ evidences the contribution of protonated phosphates and/or water molecules. Interestingly, ACPcit $0.25 \%$ seems more structured than pure synthetic ACP because of its smaller line width (FWHM $=4.75$ vs $5.80 \mathrm{ppm})$. 
TEM images reveal that ACP-cit0.25 displays particles with irregular morphology typical of ACP (Figure 2E, E'). The presence of citrate in ACP-cit2\% was investigated by ${ }^{13} \mathrm{C}$ ssNMR. Figure $\mathbf{S} 3$ compares the $\mathrm{H}_{-}{ }^{13} \mathrm{C}$ CP MAS NMR spectra of crystallized citrate used as reference (red line) and ACP-cit2\% (green line). Resonances peaks typical of citrate are observed in ACP-cit2\%: the signals at $\delta\left({ }^{13} \mathrm{C}\right)=180.4,76.5$ and $47.6 \mathrm{ppm}$ are assigned to carboxylic group, quaternary carbon and $\mathrm{CH}_{2}$ groups, respectively. ${ }^{29}$ The resonance at $\delta\left({ }^{13} \mathrm{C}\right)=168.5 \mathrm{ppm}$ ascribed to inorganic carbonate is also observed. This result indicates the presence of citrate on the surface and/or inside the core of the mineral in ACP-2\%cit. 


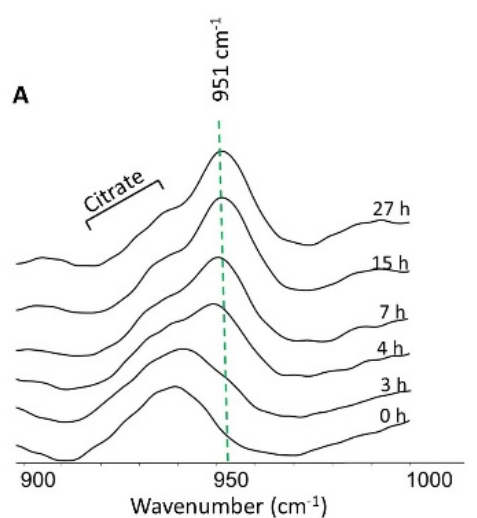

C

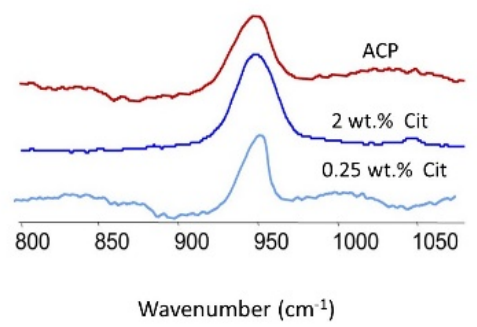

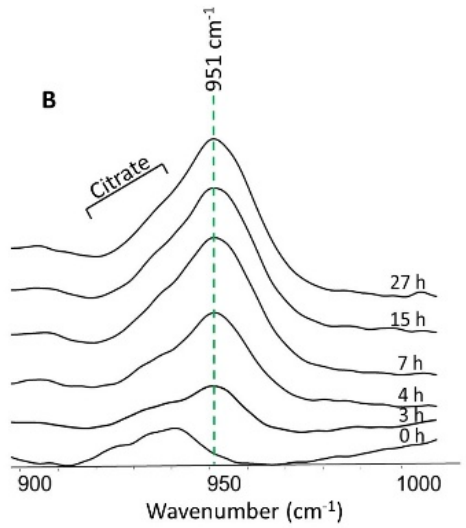

D

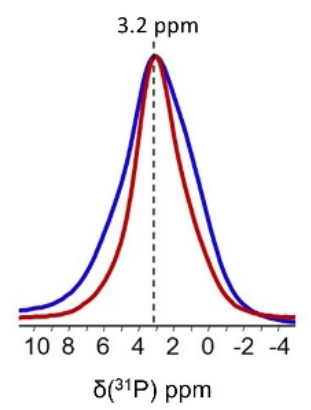

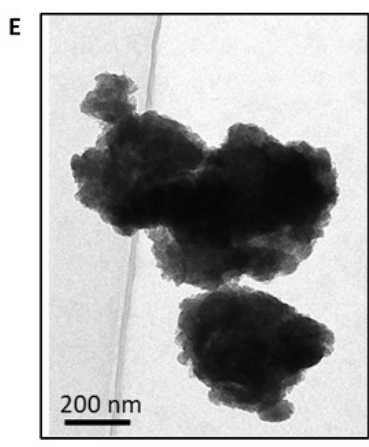

$\mathbf{E}^{\prime}$

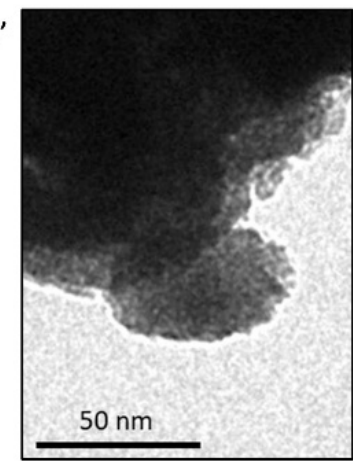

Figure 2. Formation of apatite in the presence of $2 \mathrm{wt} . \%$ and $0.25 \mathrm{wt} . \%$ citrate. (A) and (B) In situ monitoring of mineralization by Raman spectroscopy of the systems containing $2 \mathrm{wt} . \%$ and 0.25 wt.\% citrate, respectively. The blue line at $951 \mathrm{~cm}^{-1}$ and the band at $940 \mathrm{~cm}^{-1}$ represent the ACP and citrate contributions, respectively (C) Comparison of the ex situ micro-Raman spectra of ACP-Cit0.25\% (light blue line) with ACP-Cit2\% (blue line) and ACP (red line). (D) ${ }^{31} \mathrm{P}$ ssNMR spectra of ACP-cit0.25\%. Quantitative ${ }^{31} \mathrm{P}$ MAS (red line) and ${ }^{1} \mathrm{H} \rightarrow{ }^{31} \mathrm{P}$ CP MAS ( $\mathrm{t}_{\mathrm{cp}}=1 \mathrm{~ms}$, blue line) spectra of ACP-cit0.25\%. (E and E') TEM images of ACP-cit0.25\%. 
Experiments at lower concentrations of citrate (about 20 and 40 times lower than that found in vivo) were then conducted to evaluate the ability of this additive to stabilize ACP. At 0.1 and $0.05 \mathrm{wt} . \%$ citrate, the bands around $940 \mathrm{~cm}^{-1}$ assigned to carbon-carbon stretching bands are not detected in the Raman spectra due to low citrate concentration (Figure 3A-B). The broad $v_{1} \mathrm{PO}_{4}{ }^{3-}$ band at $951 \mathrm{~cm}^{-1}$ typical of ACP is observed after $\sim 5 \mathrm{~h}$ of reaction for both samples. This induction time is comparable with the 2 and 0.25 wt.\% systems ( $\sim 3 \mathrm{~h}$, Figure $2 \mathrm{~A}-\mathrm{B})$ indicating that citrate concentration (in the $0.05-2 \mathrm{wt} . \%$ range) does not play a significant role in the kinetic of ACP nucleation. Then, ACP transforms into apatite with time $\left(v_{1} \mathrm{PO}_{4}\right.$ band shift to $\left.957 \mathrm{~cm}^{-1}\right)$. However, this conversion is faster for $0.05 \mathrm{wt} . \%$ citrate: the full conversion is reached after 95 and $24 \mathrm{~h}$ for 0.1 and 0.05 wt. $\%$ citrate, respectively. Finally, OCP bands are not observed indicating that OCP did not precipitate or its concentration is lower than $10 \mathrm{w} \%{ }^{37}$

After 6 days of reaction, the apatite formed in the presence of $0.05 \mathrm{wt} \%$ citrate (CHAcit0.05\%) was isolated and characterized by ex situ micro-Raman, ssNMR and TEM (Figure 3CE). Large aggregates of platelets are observed by TEM (Figure 3C). Observations at higher magnification show that the platelets are similar to CHA in terms of size and morphology (Figure $\left.3 C^{\prime}\right) .{ }^{36}$ The way they organize is in agreement with previous observations showing that citrate may favor oriented attachment of apatite crystals. ${ }^{45}$ However, the fact that (i) TEM observations were performed under vacuum and (ii) such alignment is observed for CHA without any additives ${ }^{46}$ precludes conclusions on the role played by citrate on the particles' aggregation. The ex situ microRaman spectra of CHA and CHA-cit $0.05 \%$ are similar in terms of $\mathrm{PO}_{4}$ bands position and linewidth except for the band at $1070 \mathrm{~cm}^{-1}$ which is more intense and consistent with the presence of citrate (Figure 3D). This indicates that this additive does not induce major structural changes in apatite as confirmed by the ${ }^{31} \mathrm{P}$ MAS NMR spectrum where $\mathrm{PO}_{4}{ }^{3-}$ is in a similar chemical 
environment in both samples (Figure 3E red line vs. Figure S2). Additionally, no contribution related to OCP was detected in the ${ }^{1} \mathrm{H}^{31} \mathrm{P}$ CP NMR spectrum, which is consistent with the Raman results. This indicates that citrate allows the direct conversion of ACP into hydroxyapatite. Spectra recorded using short contact times evidence the contribution of $\mathrm{HPO}_{4}{ }^{2-}$ from the amorphous layer in the mineral (red arrow), also reported for biomimetic and bone apatite. ${ }^{46}$ 


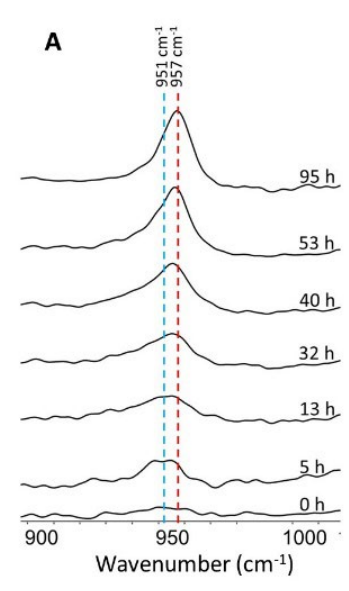

D

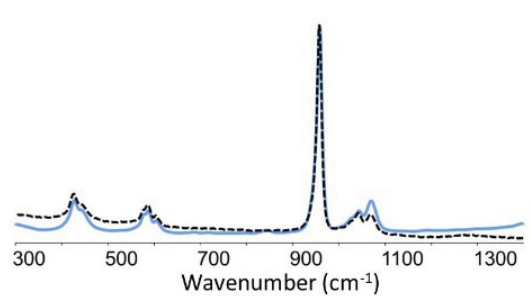

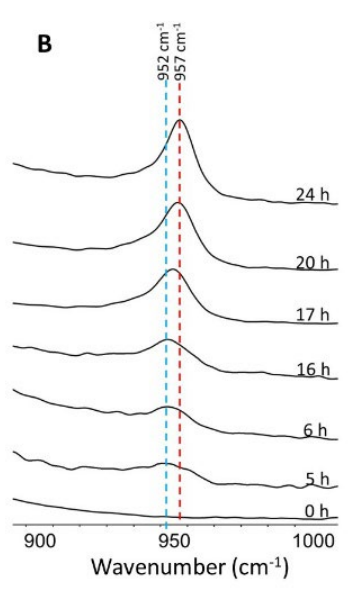
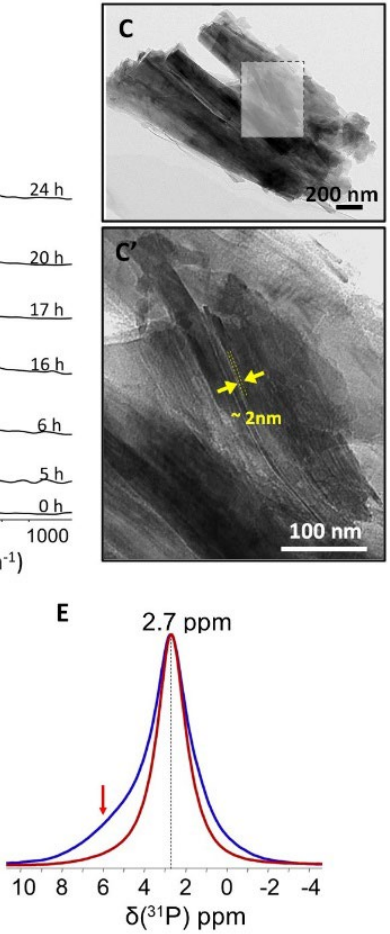

Figure 3. Formation of apatite in the presence of $0.1 \mathrm{wt} . \%$. and $0.05 \mathrm{wt} . \%$. citrate. (A) and (B) in situ monitoring by Raman spectroscopy of mineralizing systems containing $0.1 \mathrm{wt} \%$ and $0.05 \mathrm{wt} \%$ citrate, respectively. The blue line at $\sim 951 \mathrm{~cm}^{-1}$ and the red band at $\sim 957 \mathrm{~cm}^{-1}$ represent the ACP and apatite citrate contributions, respectively. (C, C') TEM images of CHA-cit0.05\%. (D) Comparison between Raman spectra of CHA-cit0.05\% (blue line) and CHA (black dashed line). (E) ${ }^{31} \mathrm{P}$ ssNMR spectra of CHAcit0.05\%. Quantitative ${ }^{31} \mathrm{P}$ MAS (red line) and ${ }^{1} \mathrm{H}^{31} \mathrm{P}$ CP MAS ( $\mathrm{t}_{\mathrm{cp}}=1 \mathrm{~ms}$; blue line) spectra. 


\subsection{Effect of collagen on CaP precipitation}

Two concentrations were first used for collagen, a low $\left(2 \mathrm{mg} \mathrm{mL} \mathrm{m}^{-1}\right)$ and a high (40 $\mathrm{mg} \mathrm{mL}^{-1}$ ). The higher one tends to mimic the environment in the biological osteoid tissue in terms of collagen concentration. ${ }^{47}$ In both cases, a band at $888 \mathrm{~cm}^{-1}$ ascribed to the stretching vibration mode of the carbonic chain from acetic acid is observed in the Raman spectra (Figure 4A-B). As the reaction evolves through the increase of $\mathrm{pH}$, this band vanishes while a new arising band ascribed to acetate ion is detected at $927 \mathrm{~cm}^{-1}$. Importantly, there is no collagen bands observed in the $\mathrm{PO}_{4}$ region.

The $2 \mathrm{mg} \mathrm{mL}^{-1}$ system was first investigated (Figure 4A). A typical band of ACP at 950 $\mathrm{cm}^{-1}$ is observed after $2 \mathrm{~h}$. The displacement of the band towards $958 \mathrm{~cm}^{1}$ (between $10 \mathrm{~h}$ and $172 \mathrm{~h}$ ) is ascribed to the progressive transformation of ACP into apatite. The sequentially band sharpening indicates that apatite undergoes maturation.

No major changes in the pathway of apatite formation are detected for the $40 \mathrm{mg} \mathrm{mL}^{-1}$ system (Figure 4B) compared to the $2 \mathrm{mg} \mathrm{mL}^{-1}$. This is in agreement with the precipitation of spherulitic crystals in both systems (Figure 4C-D). ${ }^{48}$

After 6 days of reaction, the products were isolated and characterized. The ex situ microRaman spectra of CHA-col/2mg mL $\mathrm{mL}^{-1}$ and CHA-col/40mg $\mathrm{mL}^{-1}$ (blue in Figure 4E and 4F, respectively) are compared to CHA and fresh bone. Typical bands of apatite are observed in the range of 400-1100 $\mathrm{cm}^{-1}$ namely $v_{1} \mathrm{PO}_{4}=950 \mathrm{~cm}^{-1}$ and $v_{2} \mathrm{PO}_{4}=410 \mathrm{~cm}^{-1}, v_{3} \mathrm{PO}_{4}=1010 \mathrm{~cm}^{-1}$ and $v_{4} \mathrm{PO}_{4}=550 \mathrm{~cm}^{-1}$. Collagen bands are observed around $1200 \mathrm{~cm}^{-1}$. Apatite in the samples containing collagen and fresh bone sample display similar spectral signature in terms of position and linewidth of the $v_{1} \mathrm{PO}_{4}$ band, regardless the concentration of collagen $\left(\mathrm{FWHM}\right.$ bone $=18 \mathrm{~cm}^{-}$ 1, FWHM CHA-col/2mg mL $\mathrm{mL}^{-1},=17 \mathrm{~cm}^{-1}$, FWHM CHA-col/40mg mL $\mathrm{m}^{-1}=17 \mathrm{~cm}^{-1}$ ). Conversely, 
pure $\mathrm{CHA}$ is characterized by sharper phosphate bands indicating a higher crystallinity (FWHM = $12 \mathrm{~cm}^{-1}$ ). The ex situ ${ }^{31} \mathrm{P}$ CP MAS ssNMR spectra of CHA-col 40mg mL $\mathrm{m}^{-1}$ (blue line) and pure CHA (red line) are compared in Figure 4G. CHA-col 40 $\mathrm{mg} \mathrm{mL}^{-1}$ displays a resonance peak at $\delta\left({ }^{31} \mathrm{P}\right)=3.0 \mathrm{ppm}$ characteristic of biological apatite together with a shoulder on the left indicative of amorphous layer and/or remaining ACP phase. 

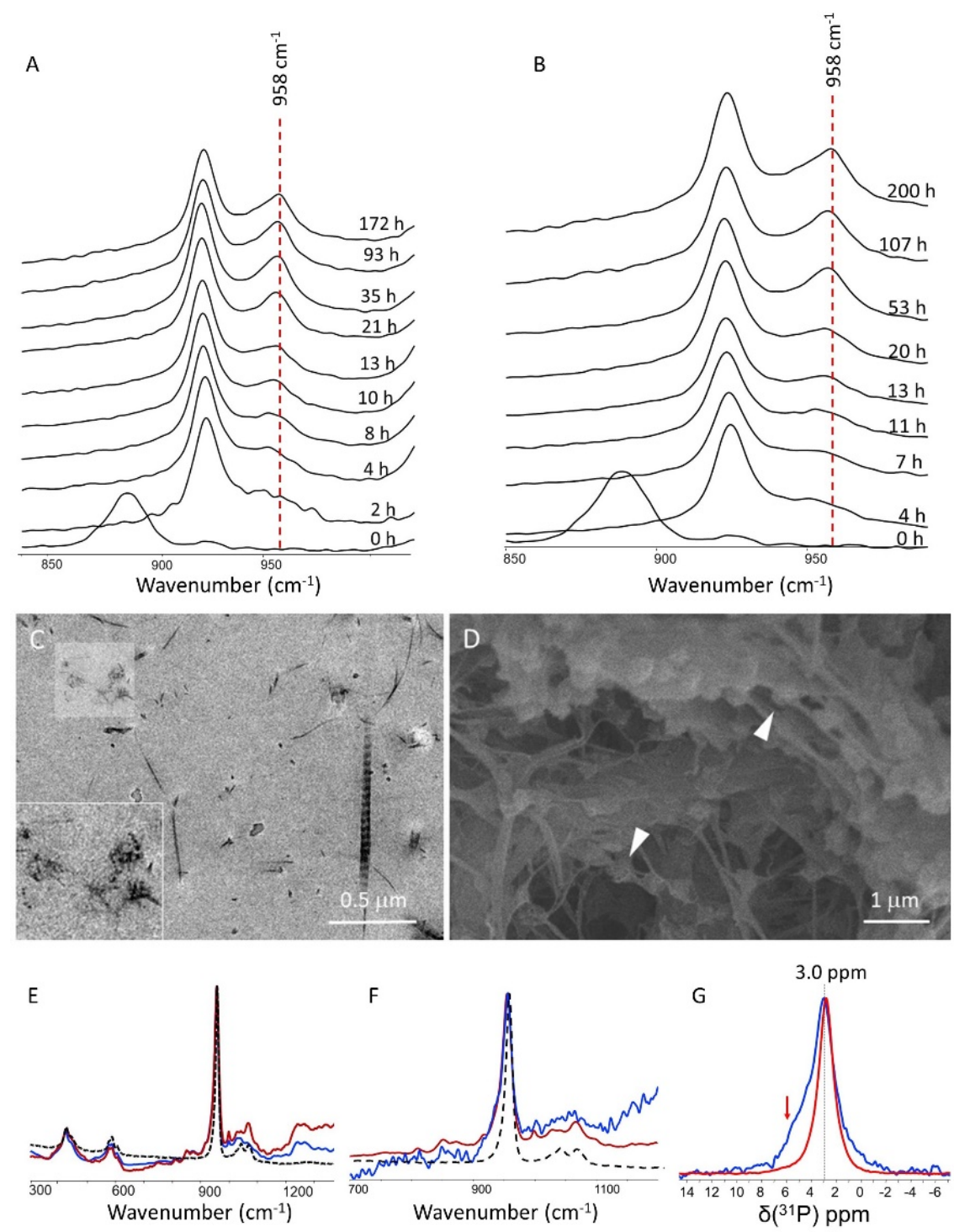

Figure 4. Formation of apatite in the presence of collagen $2 \mathrm{mg} \mathrm{mL}^{1-}$ and $40 \mathrm{mg} \mathrm{mL}^{-1}$. (A) and (B) In situ monitoring of mineralization by Raman spectroscopy of the systems containing $2 \mathrm{mg} \mathrm{mL}^{1-}$ and $40 \mathrm{mg} \mathrm{mL}^{-}$ ${ }^{1}$ collagen, respectively. The red band at $\sim 958 \mathrm{~cm}^{-1}$ corresponds to the apatite contributions. (C) TEM of ultrathin section of CHA-col/2 $\mathrm{mg} \mathrm{mL}^{-1}$ and (D) SEM micrographs of CHA-col/40 $\mathrm{mg} \mathrm{mL}^{-1}$; for both, apatite crystals aggregate into spherulites (white arrows). The light square in $\mathrm{C}$ indicates the enlarged section that is shown in the inset. (E) Comparison of the Raman spectra of CHA-col/2mg mL $\mathrm{mL}^{-1}$ (blue line) with CHA (black dashed line) and fresh bone (red line). (F) Comparison between the Raman spectra of CHA-col/40mg $\mathrm{mL}^{-1}$ (blue line), CHA (black dashed line) and fresh bone (red line). $(\mathrm{G}){ }^{31} \mathrm{P}$ CP MAS NMR spectrum ( $\mathrm{t}_{\mathrm{CP}}$ $=1 \mathrm{~ms}$ ) of CHA-Col/40 $\mathrm{mg} \mathrm{mL}^{-1}$ (blue line) and CHA (red line). 
Because osteoid tissue is not mineralized, further investigations were performed with a collagen concentration that mimics the suprafibrillar arrangement of mature bone (250 mg mL ${ }^{-1}$, Figure 5). ${ }^{12}$ In situ Raman investigations were performed in the presence of apatite ion precursors but the high collagen concentration did not allow the observation of phosphate bands in the $940-990 \mathrm{~cm}^{-1}$ region (Figure S4). Therefore, the time evolution of minerals within the $250 \mathrm{mg} \mathrm{mL}^{-1}$ collagen matrix was only investigated by ex situ ${ }^{31} \mathrm{P}$ ssNMR (Figure 5A).

At $\mathrm{t}=0$, a single narrow signal ascribed to free phosphate species in solution is observed at $\delta\left({ }^{31} \mathrm{P}\right)=0.03 \mathrm{ppm}$ (mainly $\mathrm{H}_{3} \mathrm{PO}_{4} / \mathrm{H}_{2} \mathrm{PO}_{4}{ }^{-}$at $\mathrm{pH} \sim 2$ ) with a line width of $\mathrm{FWHM}=45 \mathrm{~Hz}$. After $0.5 \mathrm{~h}$, the $\mathrm{pH}$ increases through $\mathrm{NH}_{3}$ diffusion and the resonance peak shifts to $2.7 \mathrm{ppm}$, although the linewidth remains unchanged. This is ascribed to the formation of hydrogenophosphate species (HP) related to the loss of protons in the solution. Surprisingly, this ionic species did not precipitate remaining stable in the alkaline environment until $48 \mathrm{~h}$, which contrasts with the previous systems. Indeed, ACP forms after $72 \mathrm{~h}$ as observed by the position $\delta\left({ }^{31} \mathrm{P}\right)=3.0$ and the typical broad gaussian line shape $(\mathrm{FWHM}=4.2 \mathrm{ppm})$. This induction time is much longer than that found in the control (1.5h), pAsp (11h), citrate $2.0 \mathrm{wt} . \%$ (3h) and citrate $0.0 .5 \mathrm{wt} . \%$ (5h). Finally, the signal-narrowing is observed after $100 \mathrm{~h}$ resulting in a resonance peak at $\delta\left({ }^{31} \mathrm{P}\right)=2.9$ with $\mathrm{FWHM}=1.85 \mathrm{ppm}$ that reflects the crystallization of ACP into apatite. Although the linewidth is smaller to that found for bone mineral (2.95 ppm), it is higher than that found for CHA-col $40 \mathrm{mg} \mathrm{mL}^{-1}(1.5 \mathrm{ppm})$ and for pure CHA (1.65 ppm). These results reflect the effect of collagen confinement (i.e. high fibrils density, Figure 5B) on both apatite structure and dispersion in CHA-Coll $250 \mathrm{mg} \mathrm{mL}^{-1}$ as previously shown in the literature. ${ }^{11,49}$ As seen in Figure 4D, spherulites are observed in low concentrated matrix while single particles co-align with collagen (white arrows) at bone-like concentration as observed by TEM (Figure 5C). Note that the ultrathin section is not stained to 
avoid any misleading of interpretation between heavy metals and apatite particles as previously shown. ${ }^{12}$

2D $\left\{{ }^{1} \mathrm{H}\right\}{ }^{31} \mathrm{P}$ HetCor NMR experiments were performed to characterize the mineral formed after $72 \mathrm{~h}$ (Figure 5D). Noticeably, the ${ }^{31} \mathrm{P}$ projections reveal the presence small amount of hydroxyapatite. Indeed, two distinct signals with similar chemical shifts $\delta\left({ }^{31} \mathrm{P}\right)=3.2 \mathrm{ppm}$ are observed with different linewidths: one sharp (2.9 ppm) that correlates with hydroxyl anions at $\delta\left({ }^{1} \mathrm{H}\right)=0 \mathrm{ppm}$ and one broad and more intense $(3.0 \mathrm{ppm})$ that correlates with water molecules at $\delta\left({ }^{1} \mathrm{H}\right)=4.85 \mathrm{ppm}$. Interestingly, although this suggests the coexistence of ACP and apatite in the sample formed after $72 \mathrm{~h}$ one cannot exclude the formation of apatite crystals with a high amorphous layer/crystalline core ratio. Indeed, first, the collagen/ACP signature is thinner than that of pure ACP particles in terms of linewidth ( $\mathrm{FWHM}=4.2 \mathrm{ppm}$ versus $5.8 \mathrm{ppm}$, respectively) and second, ACP resembles the amorphous layer found in bone mineral and biomimetic apatite in terms of chemical shift $\delta\left({ }^{31} \mathrm{P}\right) \mathrm{ACP} / \mathrm{Col}=3.1 \mathrm{ppm}, \delta\left({ }^{31} \mathrm{P}\right) \mathrm{ACP} /$ bone $(3.2 \mathrm{ppm})$ and $\delta\left({ }^{31} \mathrm{P}\right)$ pure $\mathrm{ACP}=3.4 \mathrm{ppm}$. 

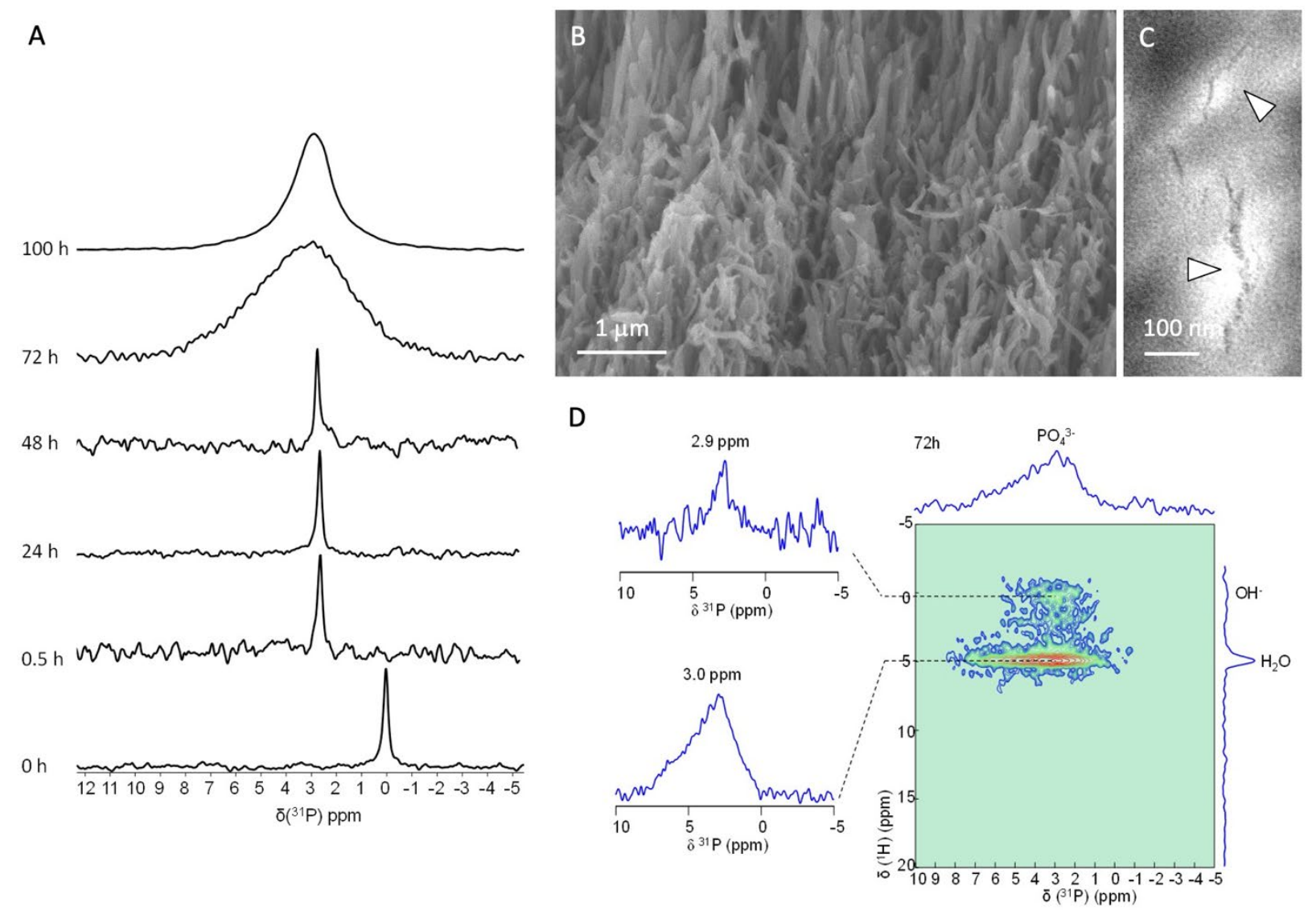

Figure 5. Formation of apatite in dense collagen matrix $\left(250 \mathrm{mg} \mathrm{mL}^{-1}\right)$. (A) Ex situ monitoring of mineralization by ${ }^{31} \mathrm{P}$ ssNMR. (B) SEM and (C) TEM images of unstained CHA-Col/250 $\mathrm{mg} \mathrm{mL}^{-1}$ section showing the high density of collagen fibrils forming a confined environment where CHA crystals coaligned with collagen (white arrows) as described in bone. (D) $2 \mathrm{D}{ }^{1} \mathrm{H}-{ }^{31} \mathrm{P}$ HetCor experiment ( $1 \mathrm{~ms}$ contact time) recorded after $480 \mathrm{~min}$ together with ${ }^{31} \mathrm{P} 1 \mathrm{D}$ spectra extracted at $\delta\left({ }^{1} \mathrm{H}\right)=0 \mathrm{ppm}$ (hydroxyl from CHA) and $\delta\left({ }^{1} \mathrm{H}\right)=5 \mathrm{ppm}$ (water molecules from ACP). 


\section{DISCUSSION}

The kinetics of $\mathrm{CaP}$ precipitation described above for pAsp, citrate and collagen are schematically summed-up in Figure 6. ACP is the first phase to form in the presence of citrate, pAsp and collagen regardless their concentrations as predicted by the Ostwald's step rule..$^{50,51}$ Compared to the control, the kinetic of ACP formation is slowdown in presence of all additives probably due to the binding of $\mathrm{Ca}^{2+}$ to the negatively charged moieties. ${ }^{52,53}$ However, we need to emphasize that aside $\mathrm{Ca}^{2+}$, the role of phosphate is so far neglected as discussed earlier. ${ }^{75}$ The formation of ACP at the early stages of bone mineralization proposed by Termine and Posner is commonly accepted. ${ }^{54}$ However, amorphous precursors remain debated in biomineralization and the nature of the first mineral phases deposited during bone formation remains as an unanswered question. ${ }^{55-59}$

The nature and lifetime of the $\mathrm{CaP}$ intermediates in vitro is controlled by the nature and concentration of the additives, e.g. brushite is not detected and OCP is rarely found in the present work. pAsp is shown to enhance the stability of ACP with respect to OCP in the control experiment, as evidenced by both in situ Raman and ${ }^{31} \mathrm{P}$ ssNMR. Conversely, in the presence of citrate $(0.05 \mathrm{wt} . \%)$ and collagen, ACP crystallizes directly into apatite without forming OCP. These results suggest that the additives modify kinetic and mechanism by which apatite forms. Indeed, citrate has been shown to stabilize apatite over other $\mathrm{CaP}$ phases i.e. OCP and brushite, possibly by different mechanisms including a decrease in the surface energy barrier ${ }^{28}$, a spatial citrate/apatite crystallographic match ${ }^{29}$, and a selective binding between $\mathrm{Ca}^{2+}$ and carboxyl group of citrate ${ }^{60}$ Here, the noticeable difference between collagen and citrate is the lifetime of ACP. Indeed, collagen leads to the formation of a transient $\mathrm{ACP}$ while citrate prevents $\mathrm{ACP}$ from crystallization at physiological concentration (for $\mathrm{t}<6$ days). ${ }^{31} \mathrm{P}$ and ${ }^{13} \mathrm{C}$ ssNMR confirms the 
binding of citrate ions onto the surface of ACP which is reported to decrease the exposition of the mineral to the solution ${ }^{44}$ and to stabilize it in solution thanks to electrostatic repulsion. ${ }^{61}$

Strikingly, precipitations in the presence of different concentrations of collagen revealed that highly concentrated matrices with a cholesteric geometry typical of compact bone stabilizes an ionic species prior to the nucleation of ACP-apatite. This suggests that collagen acts either as additives or as organic scaffold below and above the liquid-crystal threshold, respectively. The observation of such long-term stabilized ionic species suggests a steady-state local phosphate supersaturation induced by collagen suprafibrillar organization raising interesting questions regarding the role of collagen concentration on bone mineralization. It is not possible to distinguish whether ACP is found as transient apatite precursor phase or as a surface layer of apatite ${ }^{43}$ by the ${ }^{1} \mathrm{H}_{-}{ }^{31} \mathrm{P}$ HETCOR spectra but it is worth mentioning that a high amorphous layer/crystalline core ratio decreases upon apatite maturation in vitro ${ }^{62}$ and in biological system (bone and enamel). ${ }^{63}$

Several studies have shown that NCPs and charged polymers can inhibit the nucleation and growth of apatite and promote the ACP formation. ${ }^{14,64}$ Herein, in addition to the in situ investigation of the mechanisms by which biological molecules alter the pathway of apatite mineralization, we also evaluated its impact on the structure of apatite. A fresh bone sample was used to strengthen the results.

The apatite platelets form in the presence of citrate exhibit a lateral alignment as observed by TEM (Figure 3C-C') in agreement with previous observations showing that it favors the oriented attachment of mineral crystals in bone. ${ }^{29,31,45}$ This also emphasizes that this molecule strongly interacts with the surface of minerals as showed by the ssNMR results. ${ }^{65,66}$ Besides the coordination between the negatively charged carboxylate groups and the $\mathrm{Ca}^{2+}$ ions, citrate binding on the mineral surface can also take place via $\mathrm{H}$-bonding with structural water and $\mathrm{OH}$ groups 
forming the mineral. ${ }^{67-69}$ Although Raman shows no differences between synthetic apatite (CHA) and CHA-cit, ${ }^{31} \mathrm{P}$ ssNMR reveals that the spectroscopic signature of amorphous layer in apatite tends to be closer to bone mineral in the presence of citrate (Figure 2 and 3).

It is worth mentioning that apatite mineral obtained in the presence of collagen is indistinguishable from fresh bone regardless its concentration strengthening that collagen itself directs the formation of bone apatite defining its structural properties. ${ }^{9,10,12,70-72}$ This is ascribed to the combination of stereochemistry, charge and the 3D arrangement of collagen, that provide a structural template to the oriented nucleation and growth of apatite.

Therefore, one can hypothesize that inhibitors are needed to avoid pathological mineralization in vivo. Indeed, although the body fluid is supersaturated with respect to apatite, the deposition of mineral only takes place at specific tissues thanks to the combined action of initiators and inhibitors of mineralization. Biological molecules such as citrate and NCPs, paradoxically favor physiological mineralization by selectively preventing apatite growth in solution outside the collagen scaffold. ${ }^{34,73,74}$ This is exemplified by the development of pathological calcification and the diversity of $\mathrm{CaP}$ phases found in stone diseases due to the deficiency of citrate (i.e hypocitraturia) and NCPs in the plasma and urine. ${ }^{75-77}$ Additionally, these organic components are important for the transport of ionic precursors to the mineralization sites. ${ }^{77,78}$ The carboxyl groups from the molecules chelate $\mathrm{Ca}^{2+}$ forming negatively charged complexes which are attracted to the positively charged amino acids in collagen. ${ }^{11}$ Hence, even though decreasing the concentration of free ions in solution, these complexes accumulate ionic precursors in the calcified organic matrix. ${ }^{79,14}$

All these results suggest that citrate and acidic calcium-binding NCPs are involved in the earliest stages of mineralization acting mainly in (i) the prevention of pathological mineralization and (ii) 
the delivery of $\mathrm{Ca}^{2+}$ rich complexes in the gap zones of collagen triggering locally the supersaturation towards apatite but are not crucial for the oriented growth of apatite. Complementary, current hypotheses consider a similar role for matrix vesicles which may transport and accumulate calcium and phosphate ions outside the cells, that further associate with the extracellular collagenous-based matrix ${ }^{80,81}$ Conversely, tissue-like concentration of collagen allows the formation of a biomimetic confinement that stabilizes transient ionic species even at alkaline $\mathrm{pH}$. This possibly favors supersaturation of apatite ion precursors in specific sites leading to the collagen/apatite co-alignment as reported earlier. ${ }^{12}$ Overall, these results show that collagen acts either as additives or as organic scaffold below and above the liquid-crystal threshold, respectively. This particularly meaningful since fibrils density increases from the non-mineralized osteoid to the highly mineralized mature bone tissues. ${ }^{82}$

It is important to note that the mineralization in biological systems is much more complex than in vitro models and that all these molecules should be present together with cells and a multitude of specialized molecules at different concentrations. In addition, other inorganic ions are found in bioapatite such as $\mathrm{Sr}^{2+}, 83 \mathrm{Mg}^{2+84}$ or $\mathrm{F}^{-85}$ and may influence the precipitation pathway in vivo. In this respect, further investigations are needed to understand the interplay between such organic components. ${ }^{86,87}$ 


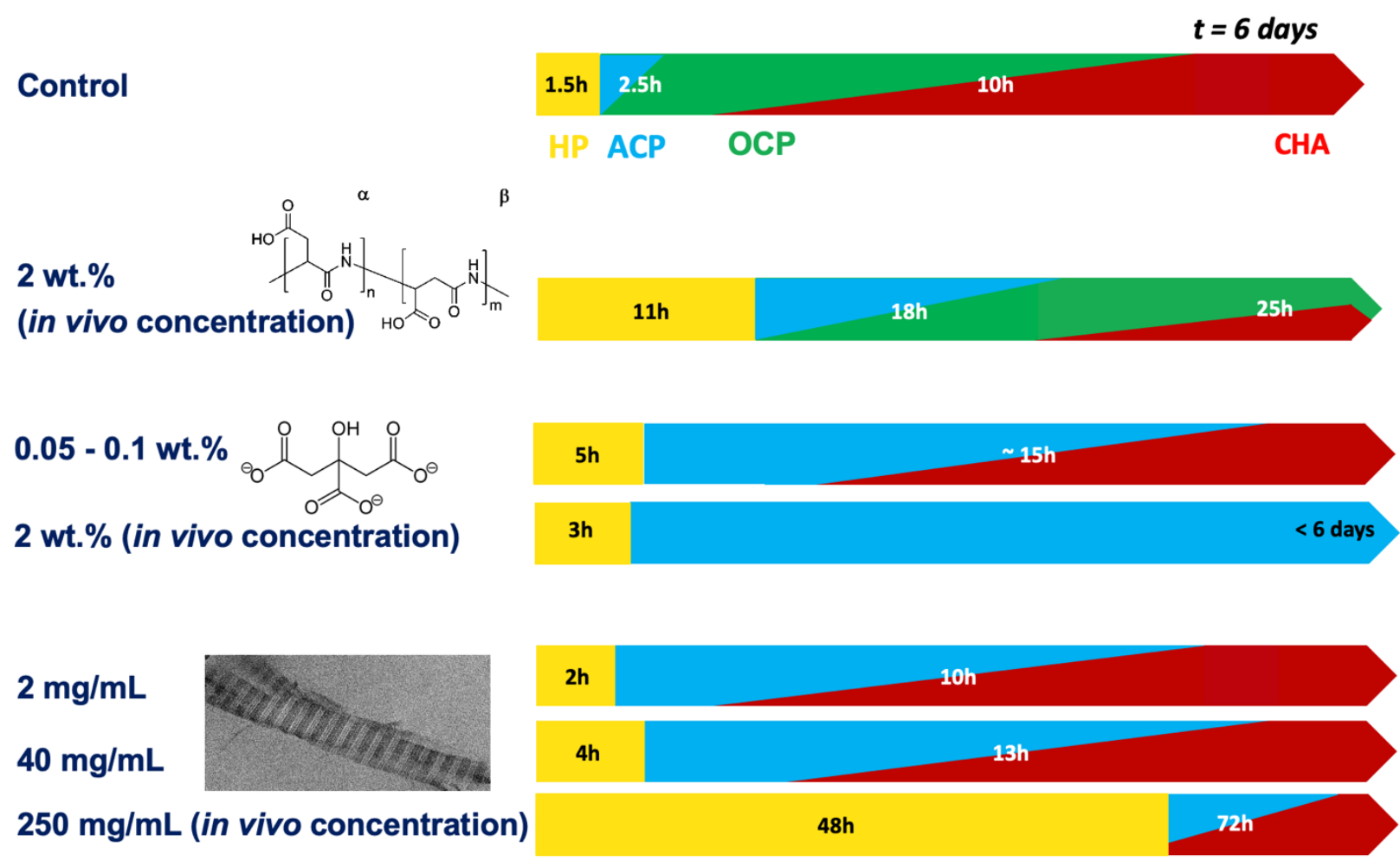

Figure 6 Schematic representation of the time scales for $\mathrm{CaP}$ precipitation without additive (control), in the presence of pAsp, citrate and collagen (HP: hydrogenphosphate ions) during 6 days. Colours and the corresponding lifetime of CaP precursors are indicated in arrows: HP (yellow), ACP (blue), OCP (green) and CHA (red) during the CaP precipitation pathway. 


\section{CONCLUSIONS}

By preserving the hydration state of both mineral and organic additives, we show here how concentration of biological components in models for bone mineralization can modulate the commonly accepted pathway of $\mathrm{CaP}$ precipitation, that is $\mathrm{ACP}, \mathrm{OCP}$ and HAP. The synthetic $\mathrm{pAsp}$ stabilizes OCP while it is inhibited by citrate. At physiological-like concentration, citrate appears to preclude HAP precipitation which only forms at very low concentration. Collagen determines the structural properties of HAP regardless of its concentration. With biomimetic high collagen concentration, ionic species are stabilized prior to the nucleation of the mineral phase. Our work highlights that confinement drives thermodynamically HAP formation by slowing down the kinetic formation of $\mathrm{CaP}$ precursors and agrees with in vivo observations showing that « $[\ldots]$ mineralization process of bone $[\ldots]$ occurs very rapidly after the self-assembly of the collagen molecules to collagen fibrils $[\ldots]^{88}$

\section{ACKNOWLEDGEMENTS}

This work was supported by French state funds managed by the ANR within the Investissements d'Avenir program under reference ANR-11-IDEX-0004-02, and more specifically within the framework of the Cluster of Excellence MATISSE led by Sorbonne Université. The authors are also grateful to Vincent Losinho from Laboratoire Réactivité de Surface, Sorbonne Université for the conception and building of the in situ Raman set up used in the presence of collagen. 


\section{ASSOCIATED CONTENT}

Additional schematic representation of the in situ Raman set up, TEM images, solid state NMR and Raman spectra.

\section{REFERENCES}

(1) Lowenstam, H. A.; Weiner, S. On Biomineralization.; Oxford University Press on Demand, 1989.

(2) Aizenberg, J.; Tkachenko, A.; Weiner, S.; Addadi, L.; Hendler, G. Calcitic Microlenses as Part of the Photoreceptor System in Brittlestars. Nature 2001, 412 (6849), 819-822.

(3) Marcus, M. A.; Amini, S.; Stifler, C. A.; Sun, C.-Y.; Tamura, N.; Bechtel, H. A.; Parkinson, D. Y.; Barnard, H. S.; Zhang, X. X. X.; Chua, J. Q. I.; et al. Parrotfish Teeth: Stiff Biominerals Whose Microstructure Makes Them Tough and Abrasion-Resistant To Bite Stony Corals. ACS Nano 2017, 11 (12), 11856-11865.

(4) Reznikov, N.; Bilton, M.; Lari, L.; Stevens, M. M.; Kröger, R. Fractal-like Hierarchical Organization of Bone Begins at the Nanoscale. Science 2018, 360 (6388).

(5) Weiner, S.; Wagner, H. D. The Material Bone: Structure-Mechanical Function Relations. Annu. Rev. Mater. Sci. 1998, 28 (1), 271-298.

(6) Blair, H.; Teitelbaum, S.; Ghiselli, R.; Gluck, S. Osteoclastic Bone Resorption by a Polarized Vacuolar Proton Pump. Science 1989, 245 (4920), 855-857.

(7) Ascenzi, A.; Bonucci, E.; Generali, P.; Ripamonti, A.; Roveri, N. Orientation of Apatite in Single Osteon Samples as Studied by Pole Figures. Calcif. Tissue Int. 1979, 29 (1), 101- 
105.

(8) Quelch, K. J.; Cole, W. G.; Melick, R. A. Noncollagenous Proteins in Normal and Pathological Human Bone. Calcif. Tissue Int. 1984, 36 (1), 545-549.

(9) Landis, W. J.; Silver, F. H. Mineral Deposition in the Extracellular Matrices of Vertebrate Tissues: Identification of Possible Apatite Nucleation Sites on Type I Collagen. Cells Tissues Organs 2008, 189 (1-4), 20-24.

(10) Silver, F. H.; Landis, W. J. Deposition of Apatite in Mineralizing Vertebrate Extracellular Matrices: A Model of Possible Nucleation Sites on Type I Collagen. Connect. Tissue Res. 2011, $52(3), 242-254$.

(11) Nudelman, F.; Pieterse, K.; George, A.; Bomans, P. H. H.; Friedrich, H.; Brylka, L. J.; Hilbers, P. A. J.; De With, G.; Sommerdijk, N. A. J. M. The Role of Collagen in Bone Apatite Formation in the Presence of Hydroxyapatite Nucleation Inhibitors. Nat. Mater. 2010, 9 (12), 1004-1009.

(12) Wang, Y.; Azaïs, T.; Robin, M.; Vallée, A.; Catania, C.; Legriel, P.; Pehau-Arnaudet, G.; Babonneau, F.; Giraud-Guille, M. M.; Nassif, N. The Predominant Role of Collagen in the Nucleation, Growth, Structure and Orientation of Bone Apatite. Nat. Mater. 2012, 11 (8), 724-733.

(13) Xu, Y. F.; Nudelman, F.; Eren, E. D.; Wirix, M. J. M.; Cantaert, B.; Nijhuis, W. H.; Hermida-Merino, D.; Portale, G.; Bomans, P. H. H.; Ottmann, C.; Friedrich, H.; Bras, W.; Akiva, A.; Orgel, J. P. R. O.; Meldrum, F. C.; Sommerdijk, N. Intermolecular Channels Direct Crystal Orientation in Mineralized Collagen. Nat. Commun. 2020, 11 (1), 1-12. 
(14) George, A.; Veis, A. Phosphorylated Proteins and Control over Apatite Nucleation, Crystal Growth, and Inhibition. Chem. Rev. 2008, 108 (11), 4670-4693.

(15) Deshpande, A. S.; Beniash, E. Bioinspired Synthesis of Mineralized Collagen Fibrils. Cryst. Growth Des. 2008, 8 (8), 3084-3090.

(16) Beniash, E.; Traub, W.; Veis, A.; Weiner, S. A Transmission Electron Microscope Study Using Vitrified Ice Sections of Predentin: Structural Changes in the Dentin Collagenous Matrix Prior to Mineralization. J. Struct. Biol. 2000, 132 (3), 212-225.

(17) Ibsen, C. J. S.; Gebauer, D.; Birkedal, H. Osteopontin Stabilizes Metastable States Prior to Nucleation during Apatite Formation. Chem. Mater. 2016, 28 (23), 8550-8555.

(18) Zhao, W.; Wang, Z.; Xu, Z.; Sahai, N. Osteocalcin Facilitates Calcium Phosphate Ion Complex Growth as Revealed by Free Energy Calculation. Phys. Chem. Chem. Phys. 2018, $20(18), 13047-13056$.

(19) Hoac, B.; Nelea, V.; Jiang, W.; Kaartinen, M. T.; McKee, M. D. Mineralization-Inhibiting Effects of Transglutaminase-Crosslinked Polymeric Osteopontin. Bone 2017, 101, 37-48.

(20) Olszta, M. J.; Odom, D. J.; Douglas, E. P.; Gower, L. B. A New Paradigm for Biomineral Formation: Mineralization via an Amorphous Liquid-Phase Precursor. Connect. Tissue Res. 2003, 44 (1), 326-334.

(21) Thula, T. T.; Svedlund, F.; Rodriguez, D. E.; Podschun, J.; Pendi, L.; Gower, L. B. Mimicking the Nanostructure of Bone: Comparison of Polymeric Process-Directing Agents. Polymers. 2010, 3 (1), 10-35. 
(22) Olszta, M. J.; Douglas, E. P.; Gower, L. B. Scanning Electron Microscopic Analysis of the Mineralization of Type I Collagen via a Polymer-Induced Liquid-Precursor (PILP) Process. Calcif. Tissue Int. 2003, 72 (5), 583-591.

(23) Jiao, K.; Niu, L. N.; Ma, C. F.; Huang, X. Q.; Pei, D. D.; Luo, T.; Huang, Q.; Chen, J. H.; Tay, F. R. Complementarity and Uncertainty in Intrafibrillar Mineralization of Collagen. Adv. Funct. Mater. 2016, 26 (38), 6858-6875.

(24) Zhou, Z.; Zhang, L.; Li, J.; Shi, Y.; Wu, Z.; Zheng, H.; Wang, Z.; Zhao, W.; Pan, H.; Wang,

Q.; et al. Polyelectrolyte-Calcium Complexes as a Pre-Precursor Induce Biomimetic Mineralization of Collagen. Nanoscale 2021, 13 (2), 953-967.

(25) Dickens, F. The Citric Acid Content of Animal Tissues, with Reference to Its Occurrence in Bone and Tumour. Biochem. J. 1941, 35 (8-9), 1011-1023.

(26) Reid, D. G.; Duer, M. J.; Jackson, G. E.; Murray, R. C.; Rodgers, A. L.; Shanahan, C. M. Citrate Occurs Widely in Healthy and Pathological Apatitic Biomineral: Mineralized Articular Cartilage, and Intimal Atherosclerotic Plaque and Apatitic Kidney Stones. Calcif. Tissue Int. 2013, 93 (3), 253-260.

(27) Schwarcz, H. P.; Agur, K.; Jantz, L. M. A New Method for Determination of Postmortem Interval: Citrate Content of Bone. J. Forensic Sci. 2010, 55 (6), 1516-1522.

(28) Jiang, W.; Chu, X.; Wang, B.; Pan, H.; Xu, X.; Tang, R. Biomimetically Triggered Inorganic Crystal Transformation by Biomolecules: A New Understanding of Biomineralization. J. Phys. Chem. B 2009, 113 (31), 10838-10844. 
(29) Hu, Y. Y.; Rawal, A.; Schmidt-Rohr, K. Strongly Bound Citrate Stabilizes the Apatite Nanocrystals in Bone. Proc. Natl. Acad. Sci. 2010, 107 (52), 22425-22429.

(30) Xie, B.; Nancollas, G. H. How to Control the Size and Morphology of Apatite Nanocrystals in Bone. Proc. Natl. Acad. Sci. 2010, 107 (52), 22369-22370.

(31) Davies, E.; Müller, K. H.; Wong, W. C.; Pickard, C. J.; Reid, D. G.; Skepper, J. N.; Duer, M. J. Citrate Bridges between Mineral Platelets in Bone. Proc. Natl. Acad. Sci. 2014, 111 (14), E1354-E1363.

(32) Degli Esposti, L.; Adamiano, A.; Tampieri, A.; Ramirez-Rodriguez, G. B.; Siliqi, D.; Giannini, C.; Ivanchenko, P.; Martra, G.; Lin, F. H.; Delgado-López, J. M.; et al. Combined Effect of Citrate and Fluoride Ions on Hydroxyapatite Nanoparticles. Cryst. Growth Des. 2020, 20 (5), 3163-3172.

(33) Santos, C.; Almeida, M. M.; Costa, M. E. Morphological Evolution of Hydroxyapatite Particles in the Presence of Different Citrate:Calcium Ratios. Cryst. Growth Des. 2015, 15 (9), 4417-4426.

(34) Shao, C.; Zhao, R.; Jiang, S.; Yao, S.; Wu, Z.; Jin, B.; Yang, Y.; Pan, H.; Tang, R. Citrate Improves Collagen Mineralization via Interface Wetting: A Physicochemical Understanding of Biomineralization Control. Adv. Mater. 2018, 30 (8), 1-7.

(35) Saxena, N.; Habelitz, S.; Marshall, G. W.; Gower, L. B. Remineralization of Demineralized Dentin Using a Dual Analog System. Orthod. Craniofac. Res. 2019, 22 (S1), 76-81.

(36) Nassif, N.; Martineau, F.; Syzgantseva, O.; Gobeaux, F.; Willinger, M.; Coradin, T.; 
Cassaignon, S.; Azaïs, T.; Giraud-Guille, M. M. In Vivo Inspired Conditions to Synthesize Biomimetic Hydroxyapatite. Chem. Mater. 2010, 22 (12), 3653-3663.

(37) Robin, M.; Euw, S. Von; Renaudin, G.; Gomes, S.; Krafft, J.; Nassif, N.; Costentin, G. Insights into OCP Identification and Quantification in the Context of Apatite Biomineralization. CrystEngComm 2020, 22 (16), 2728-2742.

(38) Somrani, S.; Banu, M.; Jemal, M.; Rey, C. Physico-Chemical and Thermochemical Studies of the Hydrolytic Conversion of Amorphous Tricalcium Phosphate into Apatite. J. Solid State Chem. 2005, 178 (5), 1337-1348.

(39) Giraud Guille, M. M.; Helary, C.; Vigier, S.; Nassif, N. Dense Fibrillar Collagen Matrices for Tissue Repair. Soft Matter 2010, 6 (20), 4963.

(40) Gobeaux, F.; Belamie, E.; Mosser, G.; Davidson, P.; Panine, P.; Giraud-Guille, M. M. Cooperative Ordering of Collagen Triple Helices in the Dense State. Langmuir 2007, 23 (11), 6411-6417.

(41) Helary, C.; Foucault-Bertaud, A.; Godeau, G.; Coulomb, B.; Giraud Guille, M. M. Fibroblast Populated Dense Collagen Matrices: Cell Migration, Cell Density and Metalloproteinases Expression. Biomaterials 2005, 26 (13), 1533-1543.

(42) Wang, Y.; Silvent, J.; Robin, M.; Babonneau, F.; Meddahi-Pellé, A.; Nassif, N.; Giraud Guille, M. M. Controlled Collagen Assembly to Build Dense Tissue-like Materials for Tissue Engineering. Soft Matter 2011, 7 (20), 9659-9664.

(43) Bergman, I.; Loxley, R. Two Improved and Simplified Methods for the Spectrophotometric 
Determination of Hydroxyproline. Anal. Chem. 1963, 35 (12), 1961-1965.

(44) Chatzipanagis, K.; Iafisco, M.; Roncal-Herrero, T.; Bilton, M.; Tampieri, A.; Kröger, R.; Delgado-López, J. M. Crystallization of Citrate-Stabilized Amorphous Calcium Phosphate to Nanocrystalline Apatite: A Surface-Mediated Transformation. CrystEngComm 2016, 18 (18), 3170-3173.

(45) Iafisco, M.; Ramírez-Rodríguez, G. B.; Sakhno, Y.; Tampieri, A.; Martra, G.; GómezMorales, J.; Delgado-López, J. M. The Growth Mechanism of Apatite Nanocrystals Assisted by Citrate: Relevance to Bone Biomineralization. CrystEngComm 2015, 17 (3), $507-511$.

(46) Wang, Y.; Von Euw, S.; Fernandes, F. M.; Cassaignon, S.; Selmane, M.; Laurent, G.; Pehau-Arnaudet, G.; Coelho, C.; Bonhomme-Coury, L.; Giraud-Guille, M. M.; et al. WaterMediated Structuring of Bone Apatite. Nat. Mater. 2013, 12 (12), 1144-1153.

(47) Griffanti, G.; Nazhat, S. N. Dense Fibrillar Collagen-Based Hydrogels as Functional Osteoid-Mimicking Scaffolds. Int. Mater. Rev. 2020, 65 (8), 502-521.

(48) Robin, M.; Almeida, C.; Azaïs, T.; Haye, B.; Illoul, C.; Lesieur, J.; Giraud-Guille, M. M.; Nassif, N.; Hélary, C. Involvement of 3D Osteoblast Migration and Bone Apatite during in Vitro Early Osteocytogenesis. Bone 2016, 88, 146-156.

(49) Kim, D.; Lee, B.; Thomopoulos, S.; Jun, Y.-S. In Situ Evaluation of Calcium Phosphate Nucleation Kinetics and Pathways during Intra- and Extrafibrillar Mineralization of Collagen Matrices. Cryst. Growth Des. 2016, 16 (9), 5359-5366. 
(50) Navrotsky, A. Energetic Clues to Pathways to Biomineralization: Precursors, Clusters, and Nanoparticles. Proc. Natl. Acad. Sci. 2004, 101 (33), 12096-12101.

(51) Wang, L.; Nancollas, G. H. Calcium Orthophosphates: Crystallization and Dissolution. Chem. Rev. 2008, 108 (11), 4628-4669.

(52) Romberg, R. W.; Werness, P. G.; Riggs, B. L.; Mann, K. G. Inhibition of Hydroxyapatite Crystal Growth by Bone-Specific and Other Calcium-Binding Proteins. Biochemistry 1986, $25(5), 1176-1180$.

(53) Hunter, G. K.; Hauschka, P. V.; Poole, R. A.; Rosenberg, L. C.; Goldberg, H. A. Nucleation and Inhibition of Hydroxyapatite Formation by Mineralized Tissue Proteins. Biochem. J. 1996, 317 (1), 59-64.

(54) Termine, J. D.; Posner, A. S. Infrared Analysis of Rat Bone: Age Dependency of Amorphous and Crystalline Mineral Fractions. Science. 1966, 153 (3743), 1523-1525.

(55) Rey, C.; Combes, C.; Drouet, C.; Glimcher, M. J. Bone Mineral: Update on Chemical Composition and Structure. Osteoporos. Int. 2009, 20 (6), 1013-1021.

(56) Boonrungsiman, S.; Gentleman, E.; Carzaniga, R.; Evans, N. D.; Mccomb, D. W. The Role of Intracellular Calcium Phosphate in Osteoblast-Mediated Bone Apatite Formation. Proc. Natl. Acad. Sci. 2012, 109 (35), 14170-14175.

(57) Akiva, A.; Kerschnitzki, M.; Pinkas, I.; Wagermaier, W.; Yaniv, K.; Fratzl, P.; Addadi, L.; Weiner, S. Mineral Formation in the Larval Zebra Fi Sh Tail Bone Occurs via an Acidic Disordered Calcium Phosphate Phase. J. Am. Chem. Soc. 2016, 138 (43), 14481-14487. 
(58) Mahamid, J.; Aichmayer, B.; Shimoni, E.; Ziblat, R.; Li, C.; Siegel, S.; Paris, O.; Fratzl, P.; Weiner, S.; Addadi, L. Mapping Amorphous Calcium Phosphate Transformation into Crystalline Mineral from the Cell to the Bone in Zebrafish Fin Rays. Proc. Natl. Acad. Sci. 2010, 107 (14), 6316-6321.

(59) Wang, X.; Yang, J.; Andrei, C. M.; Soleymani, L.; Grand, K. Biomineralization of Calcium Phosphate Revealed by in Situ Liquid-Phase Electron Microscopy. Commun. Chem. 2018, $1(1), 1-7$.

(60) Degli Esposti, L.; Adamiano, A.; Siliqi, D.; Giannini, C.; Iafisco, M. The Effect of Chemical Structure of Carboxylate Molecules on Hydroxyapatite Nanoparticles. A Structural and Morphological Study. Bioact. Mater. 2021, 6 (8), 2360-2371.

(61) Chen, Y.; Gu, W.; Pan, H.; Jiang, S.; Tang, R. Stabilizing Amorphous Calcium Phosphate Phase by Citrate Adsorption. CrystEngComm 2014, 16 (10), 1864-1867.

(62) Vandecandelaere, N.; Rey, C.; Drouet, C. Biomimetic Apatite-Based Biomaterials: On the Critical Impact of Synthesis and Post-Synthesis Parameters. J. Mater. Sci. Mater. Med. 2012, 23 (11), 2593-2606.

(63) Wu, Y.; Ackerman, J. L.; Kim, H. M.; Rey, C.; Barroug, A.; Glimcher, M. J. Nuclear Magnetic Resonance Spin-Spin Relaxation of the Crystals of Bone, Dental Enamel, and Synthetic Hydroxyapatites. J. Bone Miner. Res. 2002, 17 (3), 472-480.

(64) Peytcheva, A.; Cölfen, H.; Schnablegger, H.; Antonietti, M. Calcium Phosphate Colloids with Hierarchical Structure Controlled by Polyaspartates. Colloid Polym. Sci. 2002, 280 (3), $218-227$. 
(65) Ruiz-Agudo, E.; Burgos-Cara, A.; Ruiz-Agudo, C.; Ibañez-Velasco, A.; Cölfen, H.; Rodriguez-Navarro, C. A Non-Classical View on Calcium Oxalate Precipitation and the Role of Citrate. Nat. Commun. 2017, 8 (1), 1-10.

(66) Hu, Y. Y.; Liu, X. P.; Ma, X.; Rawal, A.; Prozorov, T.; Akinc, M.; Mallapragada, S. K.; Schmidt-Rohr, K. Biomimetic Self-Assembling Copolymer-Hydroxyapatite Nanocomposites with the Nanocrystal Size Controlled by Citrate. Chem. Mater. 2011, 23 (9), 2481-2490.

(67) Filgueiras, M. R. T.; Mkhonto, D.; de Leeuw, N. H. Computer Simulations of the Adsorption of Citric Acid at Hydroxyapatite Surfaces. J. Cryst. Growth 2006, 294 (1), 6068.

(68) De Leeuw, N. H.; Rabone, J. A. L. Molecular Dynamics Simulations of the Interaction of Citric Acid with the Hydroxyapatite (0001) and (0110) Surfaces in an Aqueous Environment. CrystEngComm 2007, 9 (12), 1178-1186.

(69) Wu, Y. J.; Tsai, T. W. T.; Huang, S. J.; Mou, Y.; Lin, C. J.; Chan, J. C. C. Hydrogen Bond Formation between Citrate and Phosphate Ions in Spherulites of Fluorapatite. Langmuir 2013, $29(37), 11681-11686$.

(70) Katz, E. P.; Li, S. T. Structure and Function of Bone Collagen Fibrils. J. Mol. Biol. 1973, $80(1), 1-15$.

(71) Xu, Z.; Yang, Y.; Zhao, W.; Wang, Z.; Landis, W. J.; Cui, Q.; Sahai, N. Molecular Mechanisms for Intrafibrillar Collagen Mineralization in Skeletal Tissues. Biomaterials 2015, 39, 59-66. 
(72) Wang, Y.; Von Euw, S.; Laurent, G.; Crevant, C.; Bonhomme-Coury, L.; Giraud-Guille, M. M.; Babonneau, F.; Nassif, N.; Azaïs, T. Impact of Collagen Confinement vs. Ionic Substitutions on the Local Disorder in Bone and Biomimetic Apatites. Mater. Horizons 2014, 1 (2), 224-231.

(73) Toroian, D.; Joo, E. L.; Price, P. A. The Size Exclusion Characteristics of Type I Collagen: Implications for the Role of Noncollagenous Bone Constituents in Mineralization. J. Biol. Chem. 2007, 282 (31), 22437-22447.

(74) Price, P. A.; Toroian, D.; Lim, J. E. Mineralization by Inhibitor Exclusion. The Calcification of Collagen with Fetuin. J. Biol. Chem. 2009, 284 (25), 17092-17101.

(75) Zuckerman, J. M.; Assimos, D. G. Hypocitraturia: Pathophysiology and Medical Management. Rev. Urol. 2009, 11 (3), 134-144.

(76) Giachelli, C. M. Inducers and Inhibitors of Biomineralization: Lessons from Pathological Calcification. Orthod. Craniofacial Res. 2005, 8 (4), 229-231.

(77) Stetler-Stevenson, W. G.; Veis, A. Bovine Dentin Phosphophoryn: Calcium Ion Binding Properties of a High Molecular Weight Preparation. Calcif. Tissue Int. 1987, 40 (2), 97102.

(78) Boskey, A. L.; Villarreal-Ramirez, E. Intrinsically Disordered Proteins and Biomineralization. Matrix Biol. 2016, 52-54, 43-59.

(79) He, G.; George, A. Dentin Matrix Protein 1 Immobilized on Type I Collagen Fibrils Facilitates Apatite Deposition in Vitro. J. Biol. Chem. 2004, 279 (12), 11649-11656. 
(80) Boonrungsiman, S. The Role of Intracellular Calcium Phosphate in Osteoblast-Mediated Bone Apatite Formation. Proc. Natl. Acad. Sci. 2012, 109 (35), 14170-14175.

(81) Nitiputri, K.; Ramasse, Q. M.; Autefage, H.; McGilvery, C. M.; Boonrungsiman, S.; Evans, N. D.; Stevens, M. M.; Porter, A. E. Nanoanalytical Electron Microscopy Reveals a Sequential Mineralization Process Involving Carbonate-Containing Amorphous Precursors. ACS Nano 2016, 10 (7), 6826-6835.

(82) Fornasier, V. L. Osteoid: An Ultrastructural Study. Hum. Pathol. 1977, 8 (3), 243-254.

(83) Tovani, C. B. ; Gloter, A.; Azaïs, T.; Selmane, M.; Ramos, A. P.; Nassif, N. Formation of Stable Strontium-Rich Amorphous Calcium Phosphate: Possible Effects on Bone Mineral. Acta Biomater. 2019, 92, 315-324.

(84) Geng, Z.; Cui, Z.; Li, Z.; Zhu, S.; Liang, Y.; Lu, W. W.; Yang, X. Synthesis, Characterization and the Formation Mechanism of Magnesium- and Strontium-Substituted Hydroxyapatite. J. Mater. Chem. B 2015, 3 (18), 3738-3746.

(85) Kniep, R.; Simon, P.; Rosseeva, E. Structural Complexity of Hexagonal Prismatic Crystal Specimens of Fluorapatite-Gelatine Nanocomposites: A Case Study in Biomimetic Crystal Research. Cryst. Res. Technol. 2014, 49 (1), 4-13.

(86) Silvent, J.; Robin, M.; Bussola Tovani, C.; Wang, Y.; Soncin, F.; Delgado, S.; Azaïs, T.; Sassoye, C.; Giraud-Guille, M.-M.; Sire, J.-Y.; et al. Collagen Suprafibrillar Confinement Drives the Activity of Acidic Calcium-Binding Polymers on Apatite Mineralization. Biomacromolecules 2021, acs.biomac.1c00206. 
(87) Jiang, W.; Griffanti, G.; Tamimi, F.; McKee, M. D.; Nazhat, S. N. Multiscale Structural Evolution of Citrate-Triggered Intrafibrillar and Interfibrillar Mineralization in Dense Collagen Gels. J. Struct. Biol. 2020, 212 (1), 107592.

(88) Glimcher, M. J. Bone: Nature of the Calcium Phosphate Crystals and Cellular, Structural, and Physical Chemical Mechanisms in Their Formation. Rev. Mineral. Geochemistry 2006, 64 (1), 223-282. 


\section{The concentration of bone-related organic additives}

\section{drives the pathway of apatite formation}

Marc Robin ${ }^{1 \S}$, Camila B. Tovani ${ }^{1 \xi}$, Jean-Marc Krafft ${ }^{2}$, Guylène Costentin ${ }^{2 *}$, Thierry Azaïs $^{1}$, Nadine Nassif ${ }^{*}$

TOC graphic

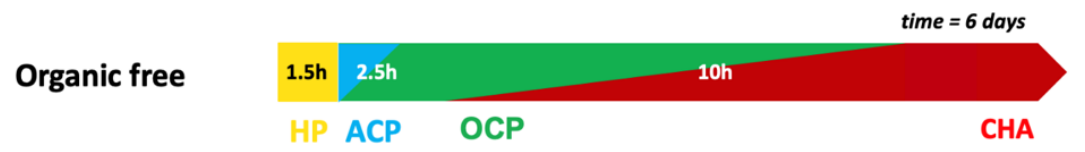

Polyaspartate
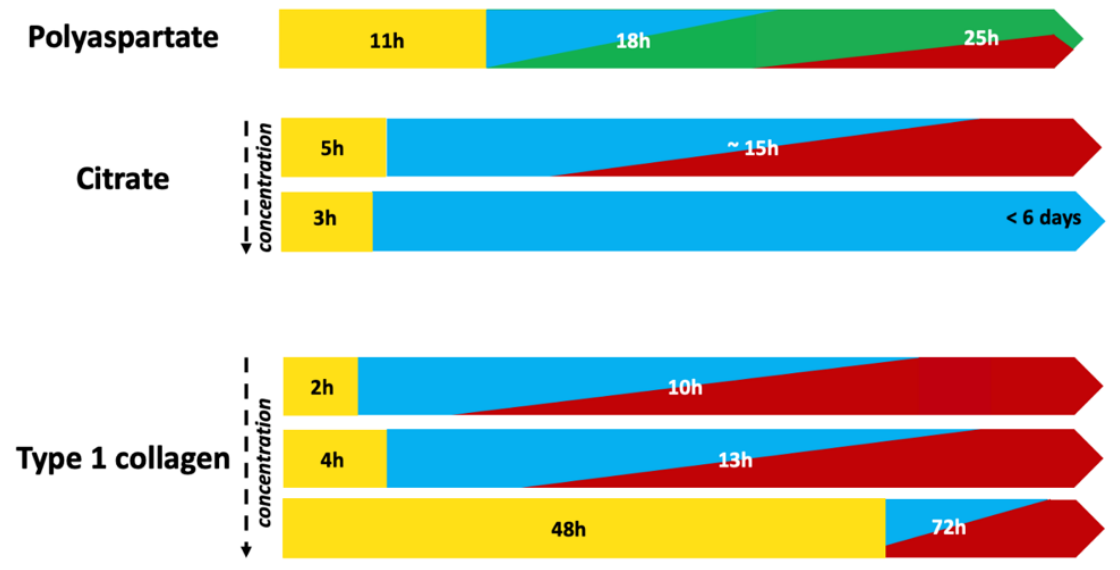

Synopsis

By playing with the concentration of bone organic additives, the work helps to identify their specific effects on apatite formation. 


\section{SUPPLEMENTARY INFORMATION}

The concentration of bone-related organic additives drives the pathway of apatite formation

Marc Robin ${ }^{1 \S}$, Camila Bussola Tovani ${ }^{1 \S}$, Jean-Marc $\mathrm{Krafft}^{2}$, Guylène Costentin ${ }^{2}$, Thierry Azaïs ${ }^{1}$, Nadine Nassif ${ }^{1 *}$

1. Sorbonne Université, CNRS, Collège de France, Laboratoire Chimie de la Matière Condensée de Paris, LCMCP, F-75005 Paris, France.

2. Sorbonne Université, CNRS, Laboratoire Réactivité de Surface, LRS, F-75005 Paris, France.

$\S$ These authors contributed equally to this work

*Corresponding author. E-mail:

guylene.costentin@sorbonne-universite.fr, nadine.nassif@sorbonne-universite.fr 


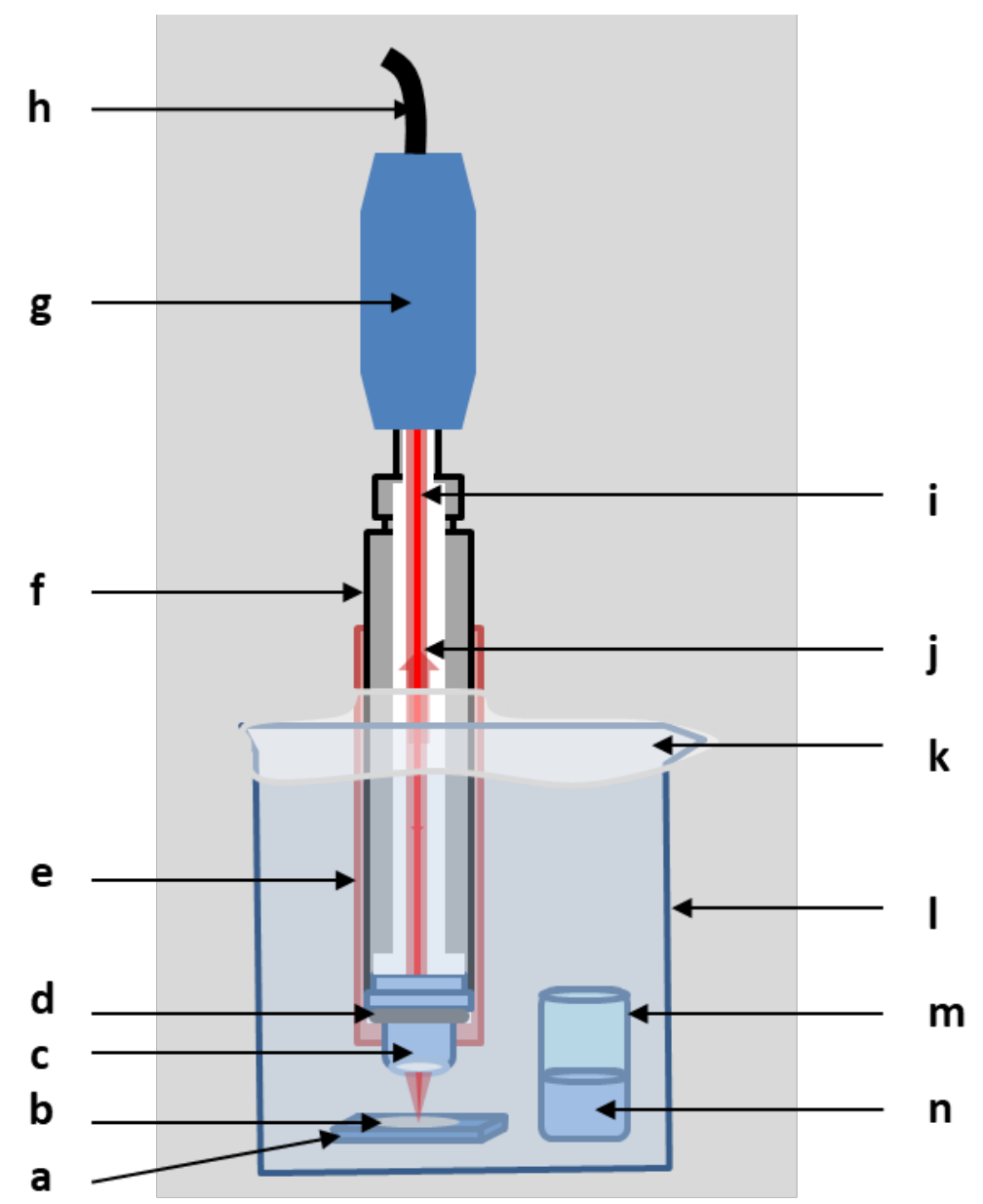

Fig. S1 Schematic representation of the homemade in situ Raman set up developped for the $\mathrm{CaP}$ formation in the presence of collagen: an aluminum tube with threaded ends carrying a 10x lens and wrapped with PTFE was screwed to the optical head.

a: quartz plate; b: sample; c; microscope lens 10x; d: O ring; e: cylindrical shell in PTFE; f: aluminum tube; g: Raman MR-Probe (Kaiser Optical Systems); h: optical fibers; i: laser beam; j: collected Raman signal; k: parafilm; 1: 1L beaker; m: flask; $\mathrm{n}: \mathrm{NH}_{3}$ 

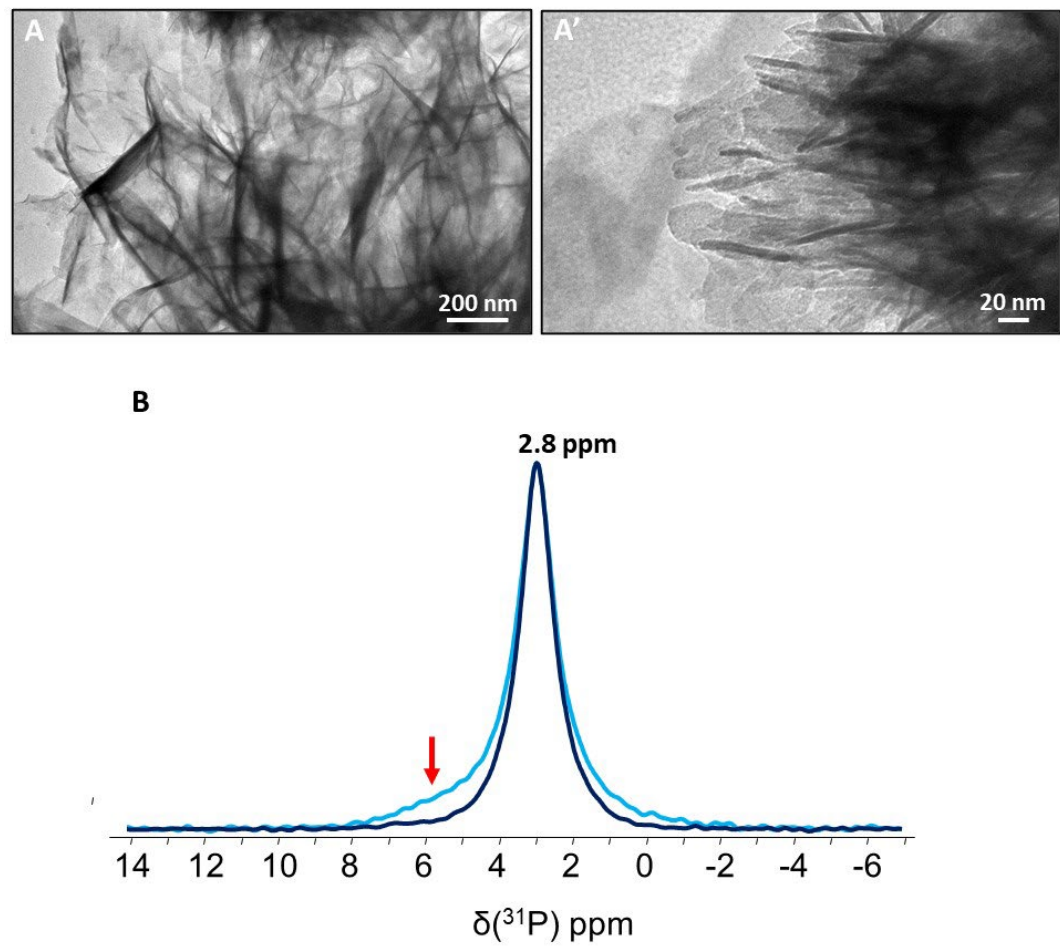

Fig. S2 (A-A') TEM images of biomimetic apatite (CHA) and (B) ${ }^{31} \mathrm{P}$ ss NMR spectra 


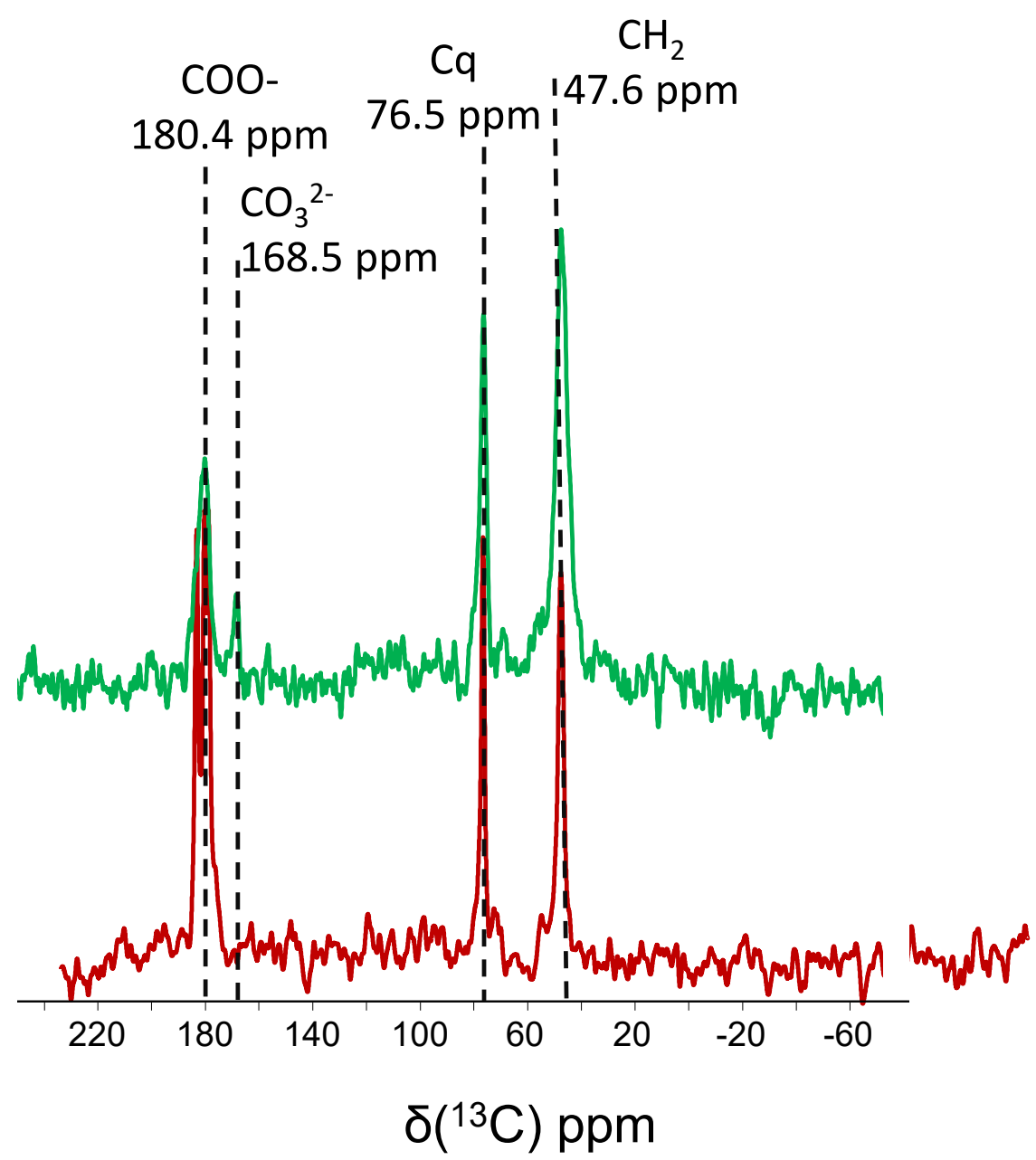

Fig. S3 Comparison of the ${ }^{1} \mathrm{H}_{-}{ }^{13} \mathrm{C}$ CP MAS ssNMR spectra $\left(\mathrm{t}_{\mathrm{CP}}=1 \mathrm{~ms}\right)$ of ACP-cit $2 \%$ (green line) and crystallized citrate (red line). Resonance peaks from citrate are observed at $\delta\left({ }^{13} \mathrm{C}\right)=180.4,76.5$ and $47.6 \mathrm{ppm}$; they are assigned to carboxylic group, quaternary carbon $(\mathrm{Cq})$ and $\mathrm{CH}_{2}$ groups, respectively. The resonance at $\delta\left({ }^{13} \mathrm{C}\right)=168.5$ ppm is due to inorganic carbonate. 


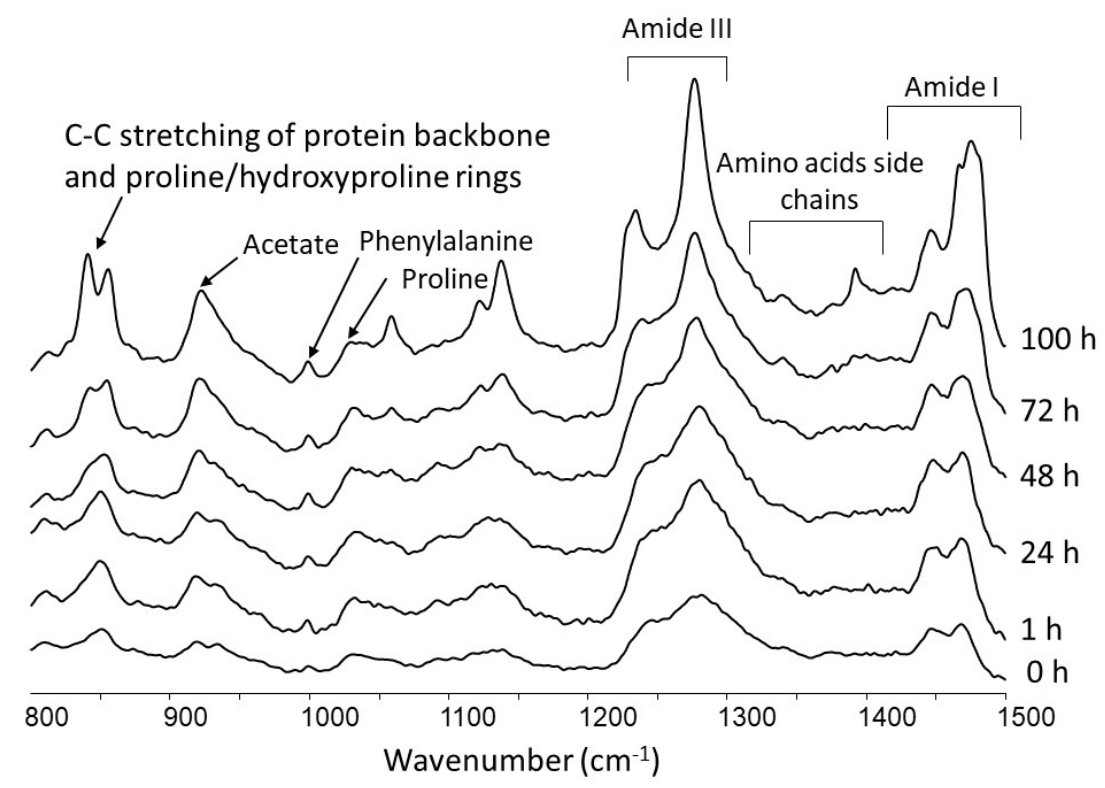

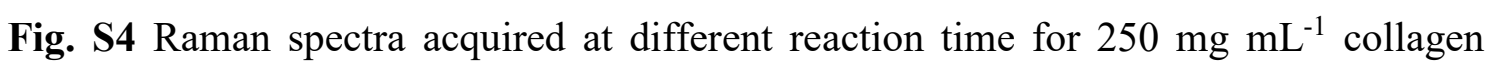
matrix containing the ionic precursors. 